\title{
Yield, Yield Components and Nutritional Traits Values of Biofortified Sorghum Hybrids in Mali
}

\author{
Alfousseiny Mahamane Maiga (Corresponding Author) \\ Research assistant at Institute of Rural Economy /Regional Centre of Applied Research of \\ Sotuba BP: 258 Bamako; PhD student in plant breeding, at West Africa Centre for Crop \\ Improvement (WACCI), College of Basic and Applied Sciences, University of Ghana, Legon \\ Baloua Nebie \\ $\mathrm{PhD}$, Senior Researcher, Plant breeder, at International Crops Research Institute for \\ Semi-Arid Tropics (ICRISAT), Bamako, Mali, PO Box 320, Bamako \\ Abdoulaye G. Diallo \\ $\mathrm{PhD}$, Senior Researcher, Plant breeder, at Institute of Rural Economy /Regional Centre of \\ Applied Research of Sotuba BP: 258 Bamako \\ Aboubacar Toure \\ $\mathrm{PhD}$, Principal Researcher, Plant breeder, at International Crops Research Institute for \\ Semi-Arid Tropics (ICRISAT), Bamako, Mali, PO Box 320, Bamako \\ Eric Danquah, Agyemang Danquah \\ $\mathrm{PhD}$, at West Africa Centre for Crop Improvement, College of Basic and Applied Sciences \\ (WACCI), University of Ghana, Legon PMB 30, Legon-Ghana
}

Received: September 28, 2021 Accepted: November 14, 2021 Published: November 17, 2021 doi:10.5296/jas.v10i1.19055

URL: https://doi.org/10.5296/jas.v10i1.19055

\begin{abstract}
To assess the adaptation, yield potential, nutrient content and to identify the traits contributing directly and indirectly to yield increase, a two years' study was conducted in four locations. Thus, a total of $28 \mathrm{~F} 1$ hybrids from two females and 14 male parents, were developed and used in this study along with the parents and four commercial hybrids. Seven (7) hybrids were identified with grain yield ranging from 4015 to $4624 \mathrm{~kg}^{-1 \text { ha }}$; heading from 64 to 92 days; iron content from 8.63 to $91.15 \mathrm{ppm}$; Zinc content from 8.14 to $28.71 \mathrm{ppm}$; lysine content from 2.73 to $5.61 \mathrm{mg} / 100 \mathrm{~g}$; threonine content from 2.50 to $6.28 \mathrm{mg} / 100 \mathrm{~g}$. For both phenotypic and genotypic levels, a significant correlation on grain yield through plant height, panicle length, primary branch per panicle, grain number per panicle and
\end{abstract}


number of whorls per panicle were found. Based on the path analysis, positive and significant direct and indirect effect of correlation were observed in this work for a cycle, grain quality, panicle length, primary branch per panicle, grain number per panicle and number of whorls per panicle at the phenotypic level.

Keywords: sorghum hybrids, direct indirect effects, genotypic and phenotypic coefficient of correlation

\section{Introduction}

Sorghum [Sorghum bicolor (L.) Moench] is one of the main cereals crops cultivated in the world. World sorghum production for the year 2017-2018 was 63 million tons on an area of 42 million ha with an average yield of $1,450 \mathrm{~kg}^{\text {-ha }}$ (FAO, 2018). It is the main source of food in many African countries, especially those in arid and semi-arid zones.

Sorghum is an important component of agriculture in industrialized countries. In Mali, it is a staple food of over $80 \%$ of the population (FAO, 2019). It is generally cultivated for both the grain, which is used as human food, and for the straw, used as fodder. Sorghum is estimated over an area of 1,500778 ha with an average yield of $1,007 \mathrm{~kg}^{-1}$ ha (DNA,2020). This low yield is mainly due to biotic and abiotic constraints such as insufficient and poor distribution of rains, the low level of soil fertility, insects and diseases, the low productive potential of local varieties. These stresses are reinforced the socio-economic conditions such as the low income of producers, the mismatch between the prices of fertilizers and that of cereals such as sorghum.

To improve this low level of productivity, several research works have been undertaken in agronomic techniques, pest control and especially varietal improvement to increase productivity and ensure sustainable food security in the West Africa region. One of the best approaches to significantly increase the production and productivity of sorghum while maintaining its adaptability and interesting characteristics is the development of F1 hybrids with characteristics of the guinea race, the most dominant in Mali as shown by Rattunde et al., (2013).

Cereals like sorghum are generally poor in amino acids and mineral content. To overcome these problems, research activities have been done across the globe and in Mali to increase the nutrient content in improved varieties. Toure et al., (2018) released varieties containing lysine, threonine, iron and zinc in Mali.

Correlation studies give information on the relationship of yield and its components then to achieve high yield, it is important to define the selection index, as the yield is a complex quantitative character and tends to be subjected to different segment characters. Thus, paths analysis explains the direct and indirect impact of part traits on grain yield and this information helps to define a solid strategy for variety selection.

The correlation studies also provide a phenotypic selection index to eliminate segregating population and selection of phenotype desirable traits. Yield improvement can be possible towards the correlation characters. According to Beil and Atkins et al. (1967), the correlation 
of grain yield with its components revealed that yield was significantly and positively correlated to a number of seeds per panicle and highly negative related to the number of heads per plant. The yield was highly and positively associated with plant height and cycle and then a negative correlation was obtained for panicle length and grain yield as reported by Bello et al., (2001) and Dewey et al., (1959). A significant phenotypic and genotypic correlation with yield owing to the indirect effect of grain number per panicle on yield was shown by plant height as reported by Johnson et al. (1955). The significant positive correlation coefficient between grain yield and panicle weight, panicle breadth, number of secondary branches and 1000grain weight as mentioned by Nimbalkar (1988). No correlation was observed for grain yield with various component traits except two characters, 1000 seed weight and a number of grains per rachis as reported by Sankarapandian et al. (1994) which may be due to elimination effects of one or other characters contributing to grain yield. Can et al., (1997) found at both genotypic and phenotypic levels a positive and high correlation between grain yield and yield components except for days to $50 \%$ flowering and days to maturity. Mahmoud (2007) revealed a significant and positive correlation between grain yield and panicle weight, grain yield and 1000 grain weight, and between 1000 grain weight and panicle weight and similarly, a significant but negative correlation exists between a number of panicle and panicle length. Plant height has high positive phenotypic and genotypic correlation coefficients with panicle weight and grain yield in sorghum.

The path coefficient analysis helps to divide the correlation coefficient into direct and indirect effects of different component traits on the grain yield. The number of grains per panicle had a significant direct effect on grain yield and then plant height had the greatest phenotypic and genotypic correlation with yield owing to the indirect effect of number of grains per panicle on yield as reported by Berenji (1988). The Number of rachis per panicle and 1000grain weight was found to be an important character for grain yield improvement as mentioned by Bidinger et al., 1993. Path coefficient analysis was carried out by Jindal \& Gill 1984 and they found that panicle weight, panicle length and cycle play an important role on grain yield and then observed positive direct and indirect effects among characters as panicle weight and panicle length. Singh \& Govila (1989) reported that the cycle and 1000 seed weight had a positive direct effect on grain yield. The heading time and days to maturity showed for most of the traits a positive and direct effect on grain yield. The positive direct effect on grain yield in sorghum was observed with the cycle, panicle length, plant height and a number of grains per panicle as reported by Eniola 2019. The positive direct effect on seed yield was found via a number of leaves per plant, panicle length, panicle weight, number of primaries per panicle and grain mould score. Improvement of grain yield can be done simultaneously by improvement of these traits listed above as reported by Deepalakshmi and Ganesamurthy (2007).

In West Africa, especially Mali, research was not focused on the nutrient content of hybrids and also on the correlation between agronomic traits, organic and inorganic content. The goal of any plant breeder is to select a genotype with various traits. The grain yield of sorghum being quantitative in nature, selection based on the grain yield is generally not very effective. Yet, selection criteria based on its component could be more efficient and reliable. 


\section{Macrothink}

Knowledge of the association between yield and its component traits and between the component parameters themselves can improve the efficiency of selection in plant breeding. In this work, the goal was to assess the association among organic, inorganic content, yield and its components to guide the breeding programs in the West Africa region.

\section{Method}

\subsection{Study Area}

The experiment was carried out in four locations Sotuba, Kolombada, Farako and Samanko Agricultural Research Stations and Sub-stations located in different regions and agroecological zones of Mali.

$>$ Regional Center for Agronomic Research (CRRA) of Sotuba: The Regional Center for Agronomic Research (CRRA) of Sotuba, IER Mali, is located in the district of Bamako and on the left bank of the Niger river about $7 \mathrm{~km}$ from downtown Bamako and covers an area of approximately 265 ha (Figure 1). The climate is Sudano-Sahelian type. Coordinates are latitude 12038', longitude 7056' and an altitude of $320 \mathrm{~m}$ with rainfall varying from 800 to more than $1000 \mathrm{~mm}$. The soil is of clay loam or clay sandy type.

$>$ Regional Center for Agronomic Research (CRRA) of Kolombada: Regional Center for Agronomic Research (CRRA) of Kolombada is located in the Koulikoro Region (commune of Fana) and about $12 \mathrm{~km}$ from Fana and covers an area of approximately 37 ha (Figure 1). Its geographic coordinates are latitude 12041', longitude 7059' and an altitude of $310 \mathrm{~m}$. The climate is Sudano-Sahelian type with an annual rainfall varying from 600 to $900 \mathrm{~mm}$. The soil is sandy loam type.

$>$ Regional Center for Agronomic Research (CRRA) of Farako: Farako Agronomic Research Sub-station is located in the Sikasso Region and about $25 \mathrm{~km}$ from Sikasso and covers an area of about 55 ha. Its geographical coordinates are latitude $14^{\circ} 48^{\prime} 0$ "N", longitude $6^{\circ} 31^{\prime} 0$ "W and an altitude of $294 \mathrm{~m}$. The climate is of the Sudano-Sahelian type with an annual rainfall varying from 1000 to $1300 \mathrm{~mm}$. The soil is of sandy loam type (Figure 1).

$>$ Regional Center for Agronomic Research (CRRA) of Samanko: Samanko agricultural research station is located west of the Bamako District on the Kangaba road. The climate is Sudano-Sahelian (latitude $12^{\circ}$ 54', longitude $08^{\circ} 4^{\prime}$, and altitude $329 \mathrm{~m}$ ) with rainfall ranging from 800 to $1000 \mathrm{~mm}$. The soil is silty-clay or sandy-clay (Figure 1). 




Figure 1. Maps of the study areas(Source: SIG, Sotuba 2020)

During 2018 -2019 from all localities, the average rainfall observed varied from 454.3 to $1235.9 \mathrm{~mm}$ (Figure 2).

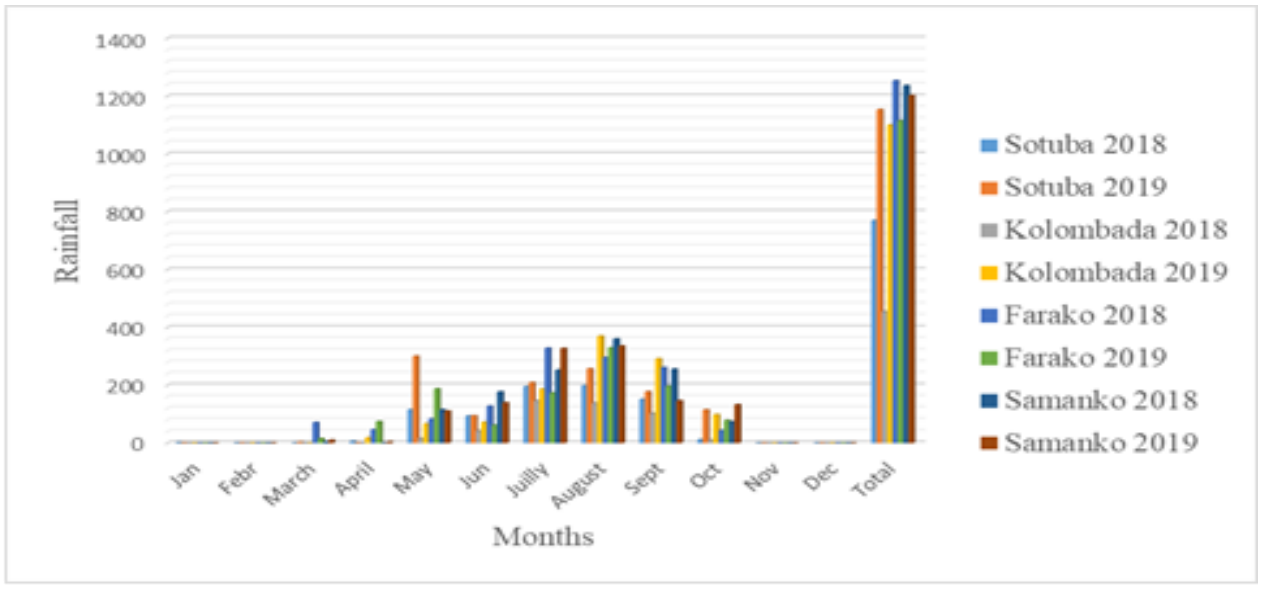

Figure 2. Rainfall amounts collected per year/ month

\subsection{Plant Material}

The plant material consisted of 28 hybrids resulting from crosses between 2 female parents (12A and 216-2P4-5A) and 14 male parents containing high organic (lysine and threonine) and inorganic (iron and zinc) content (Touré et al., 2017) (Table 1). The 28 hybrids were 
compared to the 16 parents used in crosses and to four released hybrids. The trial was conducted during two rainy seasons (2018 and 2019 years) at four zones. The parents have a diversity of agronomic traits such as plant cycle, yield, zinc, iron, lysine and threonine content (Table 1).

Table 1. Materialist of hybrids parents used to develop the biofortified hybrids with their main traits

\begin{tabular}{|c|c|c|c|c|c|c|c|c|}
\hline $\mathbf{N}^{\circ}$ & Lines & Pedigree & Cycle & $\begin{array}{l}\text { yield } \\
\left(\mathrm{kg}^{-1 \mathrm{ha}}\right)\end{array}$ & $\begin{array}{l}\text { Zinc } \\
(\mathrm{mg} / 100 \\
\mathrm{g})\end{array}$ & $\begin{array}{l}\text { Ion } \\
\text { (mg/100g) }\end{array}$ & $\begin{array}{c}\text { Lysine } \\
(\mathbf{m g} / \mathbf{1 0 0 g})\end{array}$ & $\begin{array}{l}\text { Threonine } \\
\text { (mg/100g) }\end{array}$ \\
\hline 1 & 016-BE-BC1F6-1105 & Seguifa/ Axtell5 & 68 & 1880 & 1.03 & 3.13 & 6.82 & 1.24 \\
\hline 2 & 016-BE-BC1F6-2070 & Axtell5/Grinkan & 73 & 2700 & 1.65 & 3.43 & 3.01 & 1.29 \\
\hline 3 & 016-BE-BC1F6-1048 & P721N/Grinkan & 71 & 2730 & 2.33 & 2.26 & 5.4 & 5.98 \\
\hline 4 & \multirow{2}{*}{$\begin{array}{l}\text { 016-BE-BC1F6-73 } \\
016-B E-B C 1 F 6-C T-2 \\
016\end{array}$} & Axtell5/Darrelken & 82 & 3333 & 1.19 & 2.31 & 4.67 & 0.21 \\
\hline 5 & & P721N/Grinkan & 82 & 2300 & 2.33 & 2.26 & 5.4 & 5.98 \\
\hline 6 & $\begin{array}{l}016- \\
-\mathrm{BC} 1 \mathrm{~F} 6-1053\end{array}$ & Axtell5/Grinkan & 92 & 2090 & 0.99 & 2.77 & 3.82 & 2.37 \\
\hline 7 & $\begin{array}{l}016- \\
-B C 1 F 6-1105\end{array}$ & Seguifa /Axtell5 & 83 & 923 & 1.78 & 3.18 & 4.28 & 3.96 \\
\hline 8 & $\begin{array}{l}\text { 016- } \\
- \text { BC1F6-1090 }\end{array}$ & Axtell5/Grinkan & 81 & 2800 & 1.97 & 3.33 & 6.16 & 7.06 \\
\hline 9 & $\begin{array}{l}\text { 016- } \\
\text {-BC1F6-1036 }\end{array}$ & Axtell5/Grinkan & 82 & 2580 & 1.33 & 2.57 & 2.93 & 1.06 \\
\hline 10 & $\begin{array}{l}\text { 016- } \\
\text {-BC1F6-1068 }\end{array}$ & P851171/Seguifa & 86 & 2080 & 1.62 & 5.53 & 3.2 & 0.82 \\
\hline 11 & $\begin{array}{l}\text { 016- } \\
\text {-BC1F6-1053 }\end{array}$ & Axtell5/ Grinkan & 92 & 2085 & 1.40 & 2.71 & 3.1 & 2.2 \\
\hline 12 & $\begin{array}{l}016- \\
-B C 1 F 6-1086\end{array}$ & P851171/ Seguifa & 84 & 2210 & 1.25 & 2.45 & 3.19 & 4.15 \\
\hline 13 & $\begin{array}{ll}016- & \mathrm{KO} \\
\text {-BC1F6-1050 }\end{array}$ & Axtell5/Tiandougou coura & 85 & 2019 & 1.41 & 3.38 & 2.46 & 0.24 \\
\hline 14 & 016-KO-BC1F6-9 & P851171/ Seguifa & 83 & 1333 & 1.54 & 5.16 & 2.92 & 3.26 \\
\hline & & CHECKS & & & & & & \\
\hline 15 & $12 \mathrm{~B}$ & Guinea// Caudatum & 76 & 2231 & - & - & - & - \\
\hline 16 & 216-2BP4-5 & Guinea// Caudatum & 86 & 2233 & - & - & - & - \\
\hline 17 & FADDA & 12A/Latta & 80 & 2500 & - & - & - & - \\
\hline 18 & $\begin{array}{l}\text { GRINKANYELEWO } \\
\text { LO }\end{array}$ & 150A/Grinkan & 79 & 3000 & - & - & - & - \\
\hline 19 & NIELINI & 150A/06-SB-F4DT-15 & 74 & 3000 & - & - & - & - \\
\hline 20 & SEWA & 150A/02-SB-F4-DT-298 & 78 & 2500 & - & - & - & - \\
\hline
\end{tabular}

\subsection{Experimental Design and Agronomic Practices}

The experimental design used was an Alpha lattice with 3 replications. The elementary plot was 2 rows of $3 \mathrm{~m}$. Seeding was carried out at $0.75 \mathrm{~m}$ intervals between the sowing rows and $0.30 \mathrm{~m}$ between the hills. The distance between the two blocs was $1.5 \mathrm{~m}$ and $2 \mathrm{~m}$ between replications. Thinning was done at 2 plants per hill.

The cereal complex (N (17)- $\left.\mathrm{P}_{2} \mathrm{O}_{5}(17)-\mathrm{K}_{2} \mathrm{O}(17)-\mathrm{kg}^{-1 \mathrm{ha}}\right)$ was used as fertilizer at the rate of $100 \mathrm{~kg}^{-1}$ ha or approximately $45 \mathrm{~g}$ per elementary plot, 15 days after sowing. Urea was then applied 45 days after sowing at the rate of $50 \mathrm{~kg}^{-1 \mathrm{ha}}$ or about $23 \mathrm{~g}$ per elementary plot. The in-row spreading method was used for both these fertilizer inputs.

\subsection{Data Collection}

Data were collected as described in table 2. 
Table 2. Traits measured along with the description and the units

\begin{tabular}{|c|c|c|c|}
\hline Parameters & Abbreviations & Description & Unit \\
\hline Seedling vigour & SV & $\begin{array}{l}\text { It expresses the physical energy with which the } \\
\text { seedlings emerge from the sol (height and number } \\
\text { of leaves) } 14-15 \text { days after sowing. }\end{array}$ & $\begin{array}{l}\text { Score }(5=\text { Excellent, } 1=\text { Very } \\
\text { Bad ) }\end{array}$ \\
\hline Heading time & HT & $\begin{array}{l}\text { Number of days from sowing until } 50 \% \text { of the } \\
\text { plants in the plot reach heading time. }\end{array}$ & days \\
\hline Plant height & $\mathrm{PH}$ & Distance from ground to top of panicle & $\mathrm{Cm}$ \\
\hline $\begin{array}{c}\text { Number of } \\
\text { harvested hills }\end{array}$ & $\mathrm{NHH}$ & Counting of Number of harvested hills per plot & Number \\
\hline $\begin{array}{l}\text { Panicle harvested } \\
\text { number }\end{array}$ & PHN & Counting of Panicle harvested number per plot & Number \\
\hline Panicle weight & PW & Panicle weight per plot & g/plot \\
\hline Grain Weight & GW & Grain weight per plot & g/plot \\
\hline Panicle length & PL & Distance from the basis to the top of the panicle & $\mathrm{cm}$ \\
\hline $\begin{array}{c}\text { Grain } \\
\text { number/panicle }\end{array}$ & GN/P & $\begin{array}{l}\text { Weigh the grains of all panicles in the elementary } \\
\text { plot after threshing, extrapolate with the weight of } \\
100 \text { grains. }\end{array}$ & Number \\
\hline $\begin{array}{c}\text { Number de } \\
\text { whorls /panicle }\end{array}$ & NW/P & $\begin{array}{l}\text { Counting the attachment points of the whorls of } \\
\text { primary branches }\end{array}$ & Number \\
\hline $\begin{array}{l}\text { Primary } \\
\text { branches } \\
\text { number/panicles }\end{array}$ & PBN/P & $\begin{array}{l}\text { Counting of primary branches at the level of each } \\
\text { whorls by elementary plot. }\end{array}$ & Number \\
\hline $\begin{array}{c}\text { 1000grains } \\
\text { weight }\end{array}$ & 1000GW & 1000grains weight in gram per plot & $\mathrm{g} / \mathrm{plot}$ \\
\hline $\begin{array}{l}\text { Endosperm } \\
\text { texture }\end{array}$ & GQ & $\begin{array}{l}\text { It is a visual appreciation after cutting the seed } \\
\text { longitudinally. Data were taken according to the } \\
\text { scores }\end{array}$ & $\begin{array}{c}\text { Scores: 1(Completely corneous; } \\
2 \text { (Mostly corneous); } 5 \\
\text { (Intermediate); } 7(\text { Mostly } \\
\text { starchy) and } 9 \text { (Completely } \\
\text { starchy). }\end{array}$ \\
\hline $\begin{array}{c}\text { Biochimical } \\
\text { analysis (lysine, } \\
\text { threonine, ion and } \\
\text { zinc) }\end{array}$ & BA & $\begin{array}{l}\text { After harvest, } 500 \mathrm{~g} \text { of grains were sampled and } \\
\text { sent to the lab }\end{array}$ & Content in $\mathrm{g}$ \\
\hline Remark & & $\begin{array}{c}\text { Problems or specific additional observations (leaf } \\
\text { diseases, insect damage) }\end{array}$ & By a specialist \\
\hline
\end{tabular}

In addition to these traits, zinc $(\mathrm{Zn})$ and iron $(\mathrm{Fe})$ content in whole grain was measured using energy-dispersive X-ray fluorescence spectrometry (ED-XRF).

\subsection{Statistical Analysis}

An analysis of variance (ANOVA) was carried out with the data collected using the GenStat software twelfth edition (12.1.0.3278) to assess the variability (s) of the genotypes for each trait. It was performed using the following model described by Kempthorne (Kempthorne, 1957). Genotypes were considered fixed effects, while replications and localities were considered random effects.

$$
Y i j k=\mu+L i+R_{i j}+G_{k}+(L G)_{i k}+E_{i j k}
$$

Yijk $=$ Measured variable of the $\mathrm{j}^{\text {th }}$ repetition in the $\mathrm{i}^{\text {th }}$ site of the $\mathrm{ij}^{\text {th }}$ entry

$\mu=$ Overall mean

$\mathrm{L}_{\mathrm{i}}=$ Effect of the $\mathrm{i}^{\text {th }}$ site

$\mathrm{R}_{\mathrm{ij}}=$ Effect of the $\mathrm{j}^{\text {th }}$ repetition in the $\mathrm{i}^{\text {th }}$ site 
$\mathrm{G}_{\mathrm{k}}=$ Effect of the $\mathrm{k}^{\text {th }}$ designation (parent, check and hybrids)

$(L G)_{i k}=$ Effect of the interaction of the $\mathrm{k}^{\text {th }}$ designation in the $\mathrm{i}^{\text {th }}$ site

$E_{\mathrm{ijk}}=$ Residual effects

The correlation coefficients estimation (genotypic and phenotypic) was done using the formulae suggested by Falconer (1964).

The genotypic correlation coefficient $\left(\mathrm{r}_{\mathrm{g}}\right)=\mathrm{r}\left(\mathrm{x}_{\mathrm{i}} \cdot \mathrm{x}_{\mathrm{j}}\right)_{\mathrm{g}}=\left(\left(\operatorname{Cov} .\left(\mathrm{X}_{\mathrm{i}} \cdot \mathrm{X}_{\mathrm{j}}\right)_{\mathrm{g}}\right) / \quad\left[\mathrm{V}\left(\mathrm{x}_{\mathrm{i}}\right)_{\mathrm{g}} \cdot \mathrm{V}\left(\mathrm{x}_{\mathrm{j}}\right)\right.\right.$ $\left.\mathrm{g}]^{1 / 2}\right)$

Where, $r\left(\mathrm{x}_{\mathrm{i}} \mathrm{x} \mathrm{j}\right) \mathrm{g}$ is genotypic correlation between $\mathrm{i}^{\text {th }}$ and $\mathrm{j}^{\text {th }}$ characters

Cov. $\left(\mathrm{x}_{\mathrm{i} .} \mathrm{X}_{\mathrm{j}}\right) \mathrm{g}$ is a genotypic covariance between $\mathrm{i}^{\text {th }}$ and $\mathrm{j}^{\text {th }}$ traits

$\mathrm{V}\left(\mathrm{x}_{\mathrm{i}}\right)_{\mathrm{g}}$ is a genotypic variance of $\mathrm{i}^{\text {th }}$ traits

$\mathrm{V}\left(\mathrm{x}_{\mathrm{j}}\right)_{\mathrm{g}}$ is genotypic variance of $\mathrm{j}$ th traits

The phenotype correlation coefficient $\left(r_{p}\right)=r\left(x_{i} . x_{j}\right)_{p}=\left(\left(\operatorname{Cov} .\left(x_{i} \cdot x_{j}\right)_{p}\right) /\left[V\left(x_{i}\right)_{p} . V\left(x_{j}\right)\right.\right.$ $\mathrm{p}]^{1 / 2}$ )

Where, $r\left(x_{i} \cdot x_{j}\right)_{p}$ is phenotypic correlation between $i^{\text {th }}$ and $j^{\text {th }}$ traits

Cov. $\left(\mathrm{x}_{\mathrm{i}} \cdot \mathrm{X}_{\mathrm{j}}\right)_{\mathrm{p}}$ is a phenotypic covariance between $\mathrm{i}^{\text {th }}$ and $\mathrm{j}^{\text {th }}$ traits

$\mathrm{V}\left(\mathrm{xi}_{\mathrm{i}}\right)_{\mathrm{p}}$ is a phenotypic variance of $\mathrm{i}^{\text {th }}$ traits

$\mathrm{V}\left(\mathrm{x}_{\mathrm{j}}\right)_{\mathrm{p}}$ is a phenotypic variance of $\mathrm{j}^{\text {th }}$ traits

to determine direct and indirect effects for both phenotypic and genotypic correlations levels of different component traits towards grain yield, path coefficient analysis was performed using the grain yield as a dependent variable and other independent variables. The formula used was suggested by Wright (1921) and Dewey and Lu (1959).

\section{Results}

\subsection{Agronomic Performance of Biofortified $F_{1}$ Hybrids Compared to Checks}

The analysis of variance of hybrids and checks for yield component and yield is in the table 3 . Mean square due to genotype, Genotype x Year, yearxSite, year and GenotypexYearxSite showed significant differences for all traits except zinc content for genotype, zinc, lysine and threonine for genotype $\mathrm{x}$ site level. Thus, high variability is observed between genotypes for several traits, however, this variability depends in certain cases on the environment (site and year). Further, the mean square of the repetition was not significant for all variables except grain quality and yield. This indicated that the conditions that the trials were conducted were not similar and then revealed variability within the plant materials. 
Table 3. Mean squares for all studied traits over four sites

\begin{tabular}{|c|c|c|c|c|c|c|c|c|c|}
\hline & & Cycle & Grain qualit & Plant height & Plant length & PBN/P & GN/P & NW/P & YIELD \\
\hline SOURCE & Df & \multicolumn{8}{|c|}{ m.s. } \\
\hline REPO_NO & 2 & 5.65 & $14.0057^{* *}$ & 1717 & 15.492 & 235.4 & 766297 & 9.097 & $2753204 * *$ \\
\hline DESIGNATION & 47 & $626.75^{* *}$ & $2.7238 * *$ & $39354.4 * *$ & $340.241 * *$ & $3181.8^{* *}$ & $14823228^{* *}$ & $23.802 * *$ & $16100502 * *$ \\
\hline YEAR & 1 & $91.36^{*}$ & 0.1202 & $269013.2^{* *}$ & $196.201 * *$ & $3678.4^{* *}$ & 2418936 & $502.144 * *$ & 458271934** \\
\hline DESIGNATION.YEAR & 47 & $90.34 * *$ & 0.4408 & $5546.3^{* *}$ & $26.838^{* *}$ & $345.4^{* *}$ & $4845316^{* *}$ & $7.041^{* *}$ & $5340092 * *$ \\
\hline YEAR.SITE & 6 & $1642.28 * *$ & $28.4645^{* *}$ & $21554.2^{* *}$ & $219.988 * *$ & $1002.5^{* *}$ & $21009293 * *$ & * 533.854** & $14181408^{* *}$ \\
\hline DESIGNATION.YEAR.SITE & 274 & $30.47 *$ & $1.1248 * *$ & $1134.5^{* *}$ & $32.136 * *$ & $376.2 * *$ & $3185538 * *$ & $5.44 * *$ & $1626156^{* * *}$ \\
\hline Residual & 771 & 25.72 & 0.4546 & 814.5 & 7.331 & 126.5 & 1156898 & 3.437 & 447095 \\
\hline \multirow[t]{2}{*}{ Total } & 1148 & 62.58 & 0.882 & 3006.1 & 28.913 & 327.6 & 2472879 & 8.108 & 2070525 \\
\hline & & Iron & Zinc & Lysine & Threonine & & & & \\
\hline SOURCE & d.f. & \multicolumn{4}{|c|}{ m.s. } & & & & \\
\hline REP & 95 & 71.25 & 22.58 & 0.0918 & 0.0118 & & & & \\
\hline DESIGNATION & 46 & $134.57^{* *}$ & 34.7 & $26.4769^{* *}$ & $31.7666 * *$ & & & & \\
\hline ESIGNATION.SITE & 141 & $784.37 * *$ & 26.25 & 0.2308 & 0.2425 & & & & \\
\hline Residual & 101 & 61.58 & 26.6 & 0.2103 & 0.3066 & & & & \\
\hline Total & 383 & 338.84 & 26.45 & 3.2771 & 3.9447 & & & & \\
\hline
\end{tabular}

PBN/P: primary branches number per panicle; GN/P: Grain number per panicle; NW: number of whorls per panicle; *: significant at $5 \%$ and **: significant at $1 \%$.

Mean performance of heading varied from 70 to 90 days at Farako (FA). The hybrids 12A / KO-BC1-F5-9, 216-2AP4-5 / BE-BC1-F6-73, 12A / KO-BC1-F6-1086 and 12A / SB-BC1-F6-1090 were early (73, 76 and 77 days) respectively (Table 6.2). No hybrid had the precocity of the parent KO-BC1-F5-9 (70 days) (Table 4).

At Kolombada (KO), the observed mean of heading is 78 days (Table 4). The hybrids 12A/BE-BC1-F6-73 (72 days), 12A/KO-BC1-F6-1086 (73 days), 12A/BE-BC1-F6-CT-2016 (73 days), were earliness and none hybrid got earliness as the parent KO-BC1-F6-1086 (66 days). These hybrids above were early than all checks (Table 4).

At Sotuba (SB) the heading varied between 66 and 92 days with an average of 80 days. In this locality, only the hybrids 12A/BE-BC1-F6-73 (74 days), 12A/SB-BC1-F6-1105 (76 days) and 12A/BE-BC1-F6-CT-2016 (76 days) were early than the control NIELENI (77) days) (Table 4).

The mean of heading varied between 64 and 88 days with an average of 79 days (Table 4). Hybrids 12A / KO-BC1-F5-9, 12A / BE-BC1-F6-1048 and 12A / SB-BC1-F6-1090 were early than some parents and all checks (Table 4) at Samanko.

At Farako the plant height means varied from 165 to $313.3 \mathrm{~cm}$ (Table 4). The hybrids 216-2AP4-5 / KO-BC1-F6-1053 (294.2 cm), 216-2AP4-5 / SB-BC1-F6-1053 (310.8 cm) and 216-2AP4-5 / BE-BC1- F6-73 $(313.3 \mathrm{~cm})$ were taller in terms of plant height than all controls and parents, on the other hand the hybrid 12A / BE-BC1-F6-1048 $(205.8 \mathrm{~cm})$ was short than the short plant height for hybrid check GRINKANYELEWOLO (206.7) cm (Table 4).

None hybrid got the taller plant height than the parents SB-BC1-F6-1068 $(184.2 \mathrm{~cm})$ and 12B $(184.2 \mathrm{~cm})$ at Kolombada. On the other hand, the hybrid 12A / KO-BC1-F6-1050 $(220.8 \mathrm{~cm})$ 
was substantially the same in terms of plant height as the parent KO-BC1-F6-1053 $(220.4 \mathrm{~cm})$.

At Sotuba, the hybrids 112A / BE-BC1-F6-1048 (217.5 cm), 12A / BE-BC1-F6-CT-2016 (225 $\mathrm{cm})$ had an average plant height as the control hybrids GRINKANYELEWOLO $(212,5 \mathrm{~cm})$ and SEWA $(215 \mathrm{~cm}$ ) (Table 6.2). The mean performance of plant height varied between 156.6 and $339.1 \mathrm{~cm}$ with an average of $252.2 \mathrm{~cm}$ (Table 4).

At Samanko the mean of plant height varied between 175.8 and 321.5 with an average of 248.3 cm (Table 6.2). Hybrid 12A / BE-BC1-F6-CT-2016 (204.3 cm) recorded a relatively average plant height than all control hybrids and many of the parents, the shortest plant height was recorded with the parent SB-BC1-F6- $1068(175.8 \mathrm{~cm})$ (Table 4).

At Farako the panicle length means varied from 25.16 to $37.33 \mathrm{~cm}$ (Table (4). The hybrids 216-2AP4-5/BE-BC1-F6-2070,12A/BE-BC1-F6-CT-2016,12A/BE-BC1-F6-73,216-2AP4-5/K O-BC1-F6-1050,216-2AP4-5/KO-BC1-F6-1053,12A/KO-BC1-F5-9,216-2AP4-5/SB-BC1-F61036, 216-2AP4-5/BE-BC1-F6-73, 216-2AP4-5/BE-BC1-F6-CT-2016, 12A/BE-BC1-F6-1048, 12A/BE-BC1-F6-1048, 12A/SB-BC1-F6-1036 and 216-2AP4-5/BE-BC1-F6-1048 had largest panicle length that varied from 36.33 to $33.50 \mathrm{~cm}$ than all controls and parents except a hybrid check NIELENI which got largest panicle than these above hybrids (Table 4).

None hybrid got panicle length than the check hybrid $(40.53 \mathrm{~cm})$ at Kolombada (Table 6.2). On the other hand, the hybrid 12A/BE-BC1-F6-CT-2016 (38.22 cm), 12A/KO-BC1-F6-1053 (36.50 $\mathrm{cm}), \quad$ 12A/SB-BC1-F6-1068 (36.44 cm), 12A/BE-BC1-F6-73 $\quad(36.39 \mathrm{~cm})$, 12A/BE-BC1-F6-1048 $(35.95 \mathrm{~cm})$ and 216-2AP4-5/SB-BC1-F6-1068 $(35.83 \mathrm{~cm})$ had the largest panicle length than all parents and hybrids checks (Table 4).

At Sotuba, the hybrids 12A/BE-BC1-F6-1048 ,12A/BE-BC1-F6-CT-2016, 12A/KO-BC1-F6-1053，12A/BE-BC1-F6-1105，12A/SB-BC1-F6-1090，12A/KO-BC1-F5-9, 12A/SB-BC1-F6-1036 and 12A/BE-BC1-F6-2070 which averages varied from 36.67 to 40.83 (Table 6.2). The mean performance of panicle length varied between 40.83 and $36.67 \mathrm{~cm}$ with an average of $33.13 \mathrm{~cm}$ (Table 4).

At Samanko the mean of panicle length varied between 24.71 and 39.33 with an average of $33.08 \mathrm{~cm}$ (Table 6.2). Hybrid 12A/SB-BC1-F6-1068 $(39.33 \mathrm{~cm}$ ) recorded the largest plant length of all control hybrids and parents (Table 4).

The Mean performance of a number of primary branches varied from 53 to 92 at Farako with an average of 74 (Table 4). The hybrids 112A/SB-BC1-F6-1090, 12A/BE-BC1-F6-2070, 12A/KO-BC1-F5-9, 12A/BE-BC1-F6-CT-2016, 216-2AP4-5/BE-BC1-F6-1048, 216-2AP4-5/KO-BC1-F6-1050, 216-2AP4-5/SB-BC1-F6-1036 and 12A/SB-BC1-F6-1036 had the largest number of primary branches compared to all hybrids checks and parents $(85$, 82 and 83) respectively (Table 4) except two parents. No hybrid had a number of primary branches superior to two parents KO-BC1-F5-9 (92) and BE-BC1-F6-1048 (87) (Table 4).

At Kolombada (KO), the observed mean of number of primary branches per panicle (PBN/P) is 73 (Table 6.2). The hybrids 1216-2AP4-5/SB-BC1-F6-1036 (104), 216-2AP4-5/SB-BC1-F6-1053 (102), 216-2AP4-5/KO-BC1-F6-1053 (101) and 
216-2AP4-5/BE-BC1-F6-2070 (98) recorded the largest PBN/P than all parents and hybrid checks (Table 4).

At Sotuba, the observed mean of number of primary branches per panicle (PBN/P) is 76 (Table 4). The hybrids 1216-2AP4-5/BE-BC1-F6-2070 (110), 216-2AP4-5/SB-BC1-F6-1053 (104), 216-2AP4-5/KO-BC1-F6-1053 (103), 216-2AP4-5/BE-BC1-F6-73 (100), 216-2AP4-5/SB-BC1-F6-1036 (95) and 216-2AP4-5/BE-BC1-F6-1048 (93) recorded the largest PBN/P than all parents and hybrid checks (Table 4).

The mean of PBN/P varied between 46 and 107 with an average of 76 (Table 4). Hybrids 216-2AP4-5/SB-BC1-F6-1036 (107), and 216-2AP4-5/SB-BC1-F6-1053 (104) registered the largest PBN/P than parents and hybrids check (Table 4) at Samanko.

The range of grain numbers per panicle varied from 511 to 5582 at Farako with an average of 2396 (Table 4). The hybrids 216-2AP4-5/KO-BC1-F5-9 (5582), 216-2AP4-5/SB-BC1-F6-1053 (4796), 216-2AP4-5/BE-BC1-F6-1048 (3792), 12A/SB-BC1-F6-1068 (3754), 216-2AP4-5/SB-BC1-F6-1105 (3673), 216-2AP4-5/KO-BC1-F6-1053 (3648) and 12A/SB-BC1-F6-1105 (3612) recorded higher significantly GN/P compared to all hybrids checks and parents (Table 4).

At Kolombada (KO), the observed mean of grain numbers per panicle (GN/P) is 2195 (Table 6.2). The hybrids 216-2AP4-5/BE-BC1-F6-1048 (3717), 216-2AP4-5/KO-BC1-F6-1053 (3349), 12A/KO-BC1-F6-1053(3283),216-2AP4-5/BE-BC1-F6-CT-2016(3155),216-2AP4-5/KO-BC1F5-9(3120), 216-2AP4-5/SB-BC1-F6-1053 (3051) and 12A/BE-BC1-F6-1105 (3026) were superior in producing more grain numbers per panicle compared to all parents and hybrids checks (Table 4).

At Sotuba, the grain numbers per panicle was ranged between 1405 and 4952 with an average of 2767 (Table 6.2). Twenty hybrids with 3019 to 4952 grain numbers per panicle recorded significantly GN/P than all parents and hybrid checks (Table 4).

The range of grain numbers per panicle varied between 1162 and 9298 with an average of 3049 (Table 4). Twenty-five Hybrids with 2772 to 9298 grain numbers per panicle registered in producing more GN/P than parents and hybrids checks (Table 4) at Samanko.

The range of number of whorls per panicle varied from 12 to 16 at Farako with an average of 14 for NW/P (Table 6.2). Hybrid 212A/SB-BC1-F6-1036 (16) and a parent BE-BC1-F6-2070 (16) recorded higher significantly NW/P compared to all hybrids, hybrids checks and parents (Table 4).

At Kolombada (KO), the observed mean of number of whorls per panicle (GN/P) is 2195 (Table 6.2). The hybrids 216-2AP4-5/BE-BC1-F6-CT-2016 (16), 216-2AP4-5/KO-BC1-F6-1053 (16), 216-2AP4-5/KO-BC1-F6-1050 (16), 12A/BE-BC1-F6-1048 (16), hybrids checks (FADDA (16)) and parents (BE-BC1-F6-1048 (16), 216-2AP4-5 (16)) were superior in getting number of whorls per panicle compared to others parents and hybrids checks (Table 4).

At Sotuba, the number of whorls per panicle was ranged between 10 and 15 with an average of 13 (Table 4). Hybrid 12A/BE-BC1-F6-1048 (15) recorded significantly NW/P than all parents 
and hybrid checks (Table 4).

The range of number of whorls per panicle varied between 22 and 13 with an average of 17 (Table 4). Hybrid 216-2AP4-5/SB-BC1-F6-1036 (22) registered in producing more NW/P than parents and hybrids checks (Table 4) at Samanko.

Over two years (2018 and 2019), the average grain yield is $3171 \mathrm{~kg}^{-1}$ ha (Table 4). The most productive hybrids were 216-2AP4-5 / KO-BC1-F6-1053 (4624 $\mathrm{kg}^{-1}$ ha $), 12 \mathrm{~A} /$ BE-BC1-F6-2070 (4618 kg ${ }^{-1}$ ha), 216-2AP4-5 / BE-BC1-F6-1105 (4406 kg -1 ha), 216-2AP4-5 / SB-BC1-F6-1090 (4384 $\mathrm{kg}^{-1}$ ha), 216-2AP4-5 / SB-BC1-F6-1105 (4324 $\mathrm{kg}^{-1}$ ha $), 12 \mathrm{~A} /$ SB-BC1-F6-1036 (4198 $\mathrm{kg}^{-1}$ ha), 12A / SB-BC1-F6-1105 (4116 kg -1 ha) and 216-2AP4-5 / SB-BC1-F6-1053 (4068 $\mathrm{kg}^{-1}$ ha). They were also more productive than parents and control hybrids (Table 4).

In the year 2018, the grain yield varied between $1097 \mathrm{~kg}^{-1}$ ha and $4187 \mathrm{~kg}^{-1}$ ha . The average grain yield observed was $2514 \mathrm{~kg}^{-1}$ ha. The more productive hybrids were recorded by 216-2AP4-5/KO-BC1-F6-1053 (4187 kg -1 ha), 216-2AP4-5/SB-BC1-F6-1105 (3981 $\left.\mathrm{kg}^{-1} \mathrm{ha}\right)$, 12A/BE-BC1-F6-2070 (3972 $\mathrm{kg}^{-1}$ ha), 216-2AP4-5/BE-BC1-F6-1105 (3917 $\mathrm{kg}^{-1}$ ha $)$, 216-2AP4-5/SB-BC1-F6-1090 (3870 $\mathrm{kg}^{-1}$ ha $)$, 12A/SB-BC1-F6-1105 (3737 $\mathrm{kg}^{-1}$ ha), 216-2AP4-5/SB-BC1-F6-1036 (3696 kg $\left.{ }^{-1 \mathrm{ha}}\right)$ and 216-2AP4-5/SB-BC1-F6-1068 (3506 $\left.\mathrm{kg}^{-1 \mathrm{ha}}\right)$ than all parents and hybrids checks (Table 4).

In the year 2019, the grain yield ranged between $1632 \mathrm{~kg}^{-1}$ ha and $5775 \mathrm{~kg}^{-1}$ ha . The average grain yield observed was $3802 \mathrm{~kg}^{-1}$ ha . The more productive hybrids were recorded by 12A/BE-BC1-F6-CT-2016 (5775 $\mathrm{kg}^{-1}$ ha), 12A/BE-BC1-F6-1048 (5351 $\mathrm{kg}^{-1}$ ha), 216-2AP4-5/BE-BC1-F6-2070 (5337 kg -1 ha), 216-2AP4-5/SB-BC1-F6-1053 (5333 $\left.\mathrm{kg}^{-1 \mathrm{ha}}\right)$, 12A/BE-BC1-F6-2070 (5239 $\mathrm{kg}^{-1}$ ha), 12A/SB-BC1-F6-1036 (5055 $\mathrm{kg}^{-1}$ ha $)$ and 216-2AP4-5/KO-BC1-F6-1053 (5043 $\left.\mathrm{kg}^{-1 \mathrm{ha}}\right)$ as compared to all parents and hybrids checks (Table 4).

In this study one type of endosperm texture: 2, 3 and 4 can be considered as Mostly corneous was observed (Table 4). All treatments had mostly floury endosperm texture at four sites (Table 4).

At Farako, the lysine content varied between $0.60 \mathrm{mg}$ and $5.61 \mathrm{mg} / 100 \mathrm{~g}$ (Table 4). The average lysine value for all samples is $3.14 \mathrm{mg}$. The highest content was observed in the hybrid 12A / SB-BC1-F6-1090 (5.61 mg / 100g), 216-2AP4-5 / SB-BC1-F6-1090 (5.40 mg) and 216-2AP45 / SB-BC1-F6-1036 (4.95 mg) then these contents were significantly higher than the parents and the control hybrids (Table 4).

The lysine content ranged between $0.49 \mathrm{mg}$ and $5.53 \mathrm{mg} / 100 \mathrm{~g}$ (Table 4). The average lysine value for all samples is $2.99 \mathrm{mg}$. The hybrid 216-2AP4-5 / SB-BC1-F6-1090 (5.53 mg / 100g) recorded higher significantly content of lysine compared to all others treatments (Table 4) at Kolombada, Sotuba and Samanko.

None hybrid had a higher threonine content than the parent SB-BC1-F6-1090 in Farako and Kolombada (6.05 and $6.10 \mathrm{mg} / 100 \mathrm{~g})$. On the other hand, the hybrid 12A / SB-BC1-F6-1090 
(5.94) had a high content compared to the other treatments (Table 4).

At Sotuba and Samanko, the hybrid 216-2AP4-5 / SB-BC1-F6-1090 (6.91 and $6.28 \mathrm{mg} / 100 \mathrm{~g}$ ) respectively recorded higher significantly content of threonine compared to all others treatments (Table 4).

The iron content varied from $8.63 \mathrm{ppm}$ to $39.88 \mathrm{ppm}$ (Table 4) with an average of 20.86 at Farako. The highest iron content was observed in the 216-2AP4-5 / SB-BC1-F6-1053 hybrid (39.88 ppm). The hybrid (12A / KO-BC1-F6-1050) (33.53 ppm) and the hybrid control (NIELENI) (33.71 ppm) had approximatively the same iron content (Table 4).

None hybrid had a higher iron content than the parents BE-BC1-F6-2070 (45.40 ppm) and SB-BC1-F6-1068 (42.24 ppm) at Kolombada. On the other hand, the hybrid 12A/KO-BC1-F6-1050(36.30 ppm) had a high content of iron compared to the other treatments (Table 4).

The iron content varied from $41.23 \mathrm{ppm} 95.14 \mathrm{ppm}$ (Table 4) with an average of $61.50 \mathrm{ppm}$ at Sotuba. None hybrid had a higher iron content than the parents BE-BC1-F6-2070 (95.14 ppm) while the hybrid 216-2AP4-5/KO-BC1-F6-1050 (91.15 ppm) had a high content of iron compared to the others treatments (Table 4).

At Sotuba, it should also be noted that the iron content was the highest in the other three localities and then the highest iron content was also obtained in this locality.

The iron content varied from $12.06 \mathrm{ppm}$ to $54.42 \mathrm{ppm}$ (Table 4) with an average of 30.65 at Samanko. The higher significantly iron content was observed in the hybrids 12A/KO-BC1-F6-1050 (54.42 ppm), 12A/BE-BC1-F6-CT-2016 (46.75 ppm), 12A/KO-BC1-F6-1053 (44.63 ppm), 216-2AP4-5/BE-BC1-F6-73 (40.75 ppm) and BE-BC1-F6-1048 (40.23 ppm) as compared to all others treatments.

Regarding zinc content at Farako, its content in sorghum samples varied between 21.74 and $8.14 \mathrm{ppm}$ with an average of $15.34 \mathrm{ppm}$ (Table 4). The highest content was observed with the hybrids 216-2AP4-5 / KO-BC1-F6-1086 (21.74 ppm). It is followed by the hybrid 12A / SB-BC1-F6-1105 (21.32 ppm). The content of these hybrids above was higher than all other treatments (Table 4).

The zinc content varied from $6.11 \mathrm{ppm}$ to $28.71 \mathrm{ppm}$ (Table 4) with an average of 17.03 at Kolombada. The higher significantly zinc content was observed in the hybrids

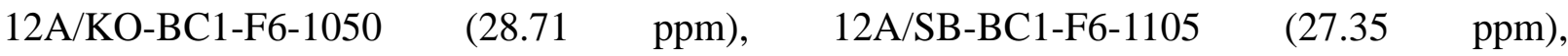
12A/SB-BC1-F6-1068 (26.04 ppm), 12A/SB-CS-BC1-F6-1053 (25.06 ppm), 12A/KO-BC1-F6-1086 (22.91), 216-2AP4-5/KO-BC1-F6-1053 (21.98 $\quad$ ppm) and 216-2AP4-5/SB-BC1-F6-1053 (21.70 ppm) than all others treatments.

The zinc content varied from $6.97 \mathrm{ppm}$ to $30.86 \mathrm{ppm}$ (Table 4) with an average of $19.54 \mathrm{ppm}$ at Sotuba. The hybrids 12A/SB-CS-BC1-F6-1053 (30.86 ppm) and 12A/SB-BC1-F6-1105 (29.93 ppm) had higher significantly zinc content than all other parents and hybrids checks (Table 4).

The zinc content varied from $7.68 \mathrm{ppm}$ to $26.79 \mathrm{ppm}$ (Table 4) with an average of $16.75 \mathrm{ppm}$ at 
Samanko. The hybrids 12A/BE-BC1-F6-2070 (26.79 ppm), 216-2AP4-5/SB-BC1-F6-1036 (26.59 ppm) and 12A/SB-CS-BC1-F6-1053 (25.77 ppm) had higher significantly zinc content than all treatments (Table 4).

Table 4. Fortified hybrids and checks performance in two years for all studied traits at four locations

\begin{tabular}{|c|c|c|c|c|c|c|c|c|c|c|c|c|c|c|c|c|}
\hline \multirow[b]{2}{*}{ Designation } & $\mathrm{A}$ & $\mathrm{KO}$ & SB & SKO & FA 1 & $\mathrm{KO}$ & SB & SKO & FA & $\mathrm{KO}$ & SB & SKO & $\mathrm{A}$ & $\mathrm{KO}$ & $\mathrm{SB}$ & SKO \\
\hline & \multicolumn{4}{|c|}{ Cycle } & \multicolumn{4}{|c|}{ Grain quality } & \multicolumn{4}{|c|}{ Plant height } & \multicolumn{4}{|c|}{ Panicle length } \\
\hline 12A/BE-BC1-F6-1048 & 79 & 76 & 77 & 75 & 4 & 2 & 2 & 2 & 205.8 & 237.5 & 217.5 & 211.6 & 34.33 & 35.95 & 40.83 & 36.50 \\
\hline $12 \mathrm{~A} /$ & 82 & 80 & 82 & 84 & 3 & 2 & 3 & 3 & 242.3 & 315.8 & 306.7 & 315.0 & 28.67 & 34.61 & 37.66 & 5.16 \\
\hline 12A/BE-BC1-F6-2070 & 87 & 81 & 85 & 85 & 3 & 2 & 2 & 3 & 249.6 & 287.5 & 261.7 & 266.5 & 32.83 & 35.11 & 36.67 & 33.38 \\
\hline 12A/BE-BC1-F6-73 & 81 & 72 & 74 & 75 & 3 & 2 & 2 & 2 & 260.0 & 327.5 & 300.0 & 271.7 & 35.00 & 36.39 & 35.83 & 35.00 \\
\hline $12 \mathrm{~A} / \mathrm{BE}-\mathrm{B}$ & 80 & 73 & 76 & 76 & 4 & 2 & 2 & 3 & 230.0 & 265.0 & 225.0 & 204.3 & 36.33 & 38.22 & 39.83 & 37.60 \\
\hline 12A/KO-BC1-F5-9 & 73 & 74 & 77 & 74 & 3 & 2 & 2 & 2 & 288.3 & 293.3 & 294.2 & 300.8 & 34.66 & 32.83 & 37.17 & 36.66 \\
\hline 12A/KO-BC1-F & 84 & 80 & 79 & 79 & 4 & 2 & 2 & 3 & 218.9 & 220.8 & 255.8 & 251.7 & 31.33 & 35.22 & 35.33 & 38.67 \\
\hline 12A/KO-BC1-F & 86 & 79 & 90 & 88 & 4 & 2 & 2 & 2 & 263.3 & 310.8 & 311.7 & 278.2 & 32.17 & 36.50 & 38.50 & 34.05 \\
\hline $12 \mathrm{~A} / \mathrm{K}$ & 77 & 73 & 77 & 76 & 4 & 2 & 2 & 2 & 238.3 & 302.5 & 282.5 & 285.0 & 32.83 & 33.78 & 34.33 & 35.66 \\
\hline 12A/SB-B & 84 & 81 & 86 & 82 & 3 & 2 & 2 & 2 & 235.0 & 255.8 & 248.3 & 255.7 & 33.67 & 34.89 & 37.00 & 36.38 \\
\hline $12 \mathrm{~A} / \mathrm{S}$ & 81 & 77 & 78 & 77 & 4 & 2 & 2 & 3 & 238.4 & 286.7 & 258.3 & 275.0 & 33.00 & 36.44 & 35.83 & 39.33 \\
\hline $12 \mathrm{~A} / \mathrm{s}$ & 77 & 74 & 78 & 75 & 4 & 2 & 2 & 3 & 288.3 & 305.8 & 300.8 & 311.7 & 33.17 & 35.00 & 37.17 & 37.00 \\
\hline $12 \mathrm{~A} / \mathrm{s}$ & 78 & 79 & 76 & 77 & 3 & 2 & 2 & 2 & 262.5 & 299.2 & 296.6 & 291.6 & 29.50 & 32.06 & 35.17 & 32.16 \\
\hline $12 \mathrm{~B}$ & 84 & 80 & 66 & 77 & 3 & 3 & 2 & 2 & 181.7 & 184.2 & 170.0 & 188.3 & 33.33 & 35.22 & 35.67 & 31.48 \\
\hline $216-2$ & 81 & 80 & 88 & 85 & 4 & 3 & 3 & 2 & 247.5 & 274.2 & 308.3 & 250.1 & 33.50 & 33.45 & 33.83 & 36.76 \\
\hline $216-$ & 84 & 80 & 85 & 83 & 4 & 3 & 2 & 3 & 272.5 & 294.2 & 307.5 & 300.8 & 27.67 & 29.61 & 31.17 & 34.14 \\
\hline $216-2$ & 82 & 81 & 85 & 83 & 4 & 3 & 4 & 2 & 226.6 & 240.8 & 262.5 & 223.2 & 35.16 & 30.61 & 33.50 & 37.72 \\
\hline $216-2$ & 76 & 77 & 81 & 79 & 4 & 3 & 3 & 3 & 313.3 & 345.8 & 339.1 & 321.5 & 34.50 & 30.72 & 33.17 & 35.55 \\
\hline $216-2$ & 84 & 80 & 83 & 83 & 4 & 3 & 3 & 2 & 238.3 & 245.8 & 271.7 & 279.1 & 34.50 & 30.45 & 33.00 & 34.48 \\
\hline 216-2AP4-5/KO-BC1-F5-9 & 84 & 81 & 86 & 82 & 3 & 3 & 3 & 3 & 250.8 & 292.5 & 280.8 & 275.0 & 31.00 & 28.67 & 30.83 & 37.50 \\
\hline $216-2$ & 82 & 82 & 85 & 85 & 4 & 2 & 3 & 3 & 243.3 & 233.3 & 263.8 & 224.8 & 34.83 & 35.33 & 36 & 36.88 \\
\hline $216-$ & 81 & 81 & 88 & 85 & 4 & 3 & 3 & 3 & 294.2 & 286.7 & 288.3 & 275.7 & 34.83 & 34.11 & 35.00 & 35.88 \\
\hline $216-2$ & 83 & 82 & 88 & 82 & 4 & 2 & 3 & 2 & 267.5 & 274.2 & 303.3 & 295.8 & 32.83 & 25.78 & 30.00 & 32.66 \\
\hline $216-2$ & 83 & 79 & 83 & 81 & 5 & 2 & 4 & 3 & 248.3 & 241.7 & 250.0 & 237.5 & 34.50 & 32.44 & 35.33 & 35.00 \\
\hline $216-$ & 84 & 82 & 86 & 86 & 4 & 3 & 4 & 3 & 310.8 & 276.7 & 265.0 & 269.0 & 34.17 & 34.06 & 35.83 & 36.21 \\
\hline $216-$ & 87 & 82 & 84 & 85 & 3 & 3 & 3 & 3 & 241.7 & 265.0 & 254.2 & 267.6 & 33.00 & 35.83 & 35.50 & 38.60 \\
\hline $216-2$ & 84 & 80 & 82 & 81 & 4 & 2 & 3 & 3 & 257.5 & 281.7 & 280.0 & 288.3 & 32.67 & 31.61 & 34.00 & 36.48 \\
\hline $216-2$ & 83 & 83 & 89 & 85 & 4 & 2 & 2 & 2 & 270.8 & 290.0 & 293.3 & 299.0 & 29.67 & 27.22 & 33.67 & 34.05 \\
\hline $216-$ & 90 & 87 & 92 & 88 & 3 & 3 & 3 & 2 & 173.3 & 188.3 & 200.8 & 185.8 & 26.50 & 27.83 & 30.83 & 31.00 \\
\hline BE-B & 80 & 80 & 79 & 80 & 3 & 3 & 3 & 2 & 220.0 & 231.7 & 230.8 & 215.8 & 30.00 & 29.39 & 29.66 & 27.33 \\
\hline BE-I & 71 & 70 & 70 & 69 & 3 & 2 & 5 & 2 & 208.3 & 221.6 & 217.5 & 209.2 & 25.67 & 21.78 & 25.33 & 25.67 \\
\hline BE-B & 75 & 75 & 79 & 76 & 4 & 3 & 4 & 3 & 200.8 & 200.0 & 193.3 & 191.5 & 28.66 & 27.28 & 28.33 & 25.38 \\
\hline BE-E & 75 & 76 & 70 & 71 & 3 & 3 & 3 & 3 & 271.6 & 315.8 & 291.7 & 302.5 & 28.17 & 30.89 & 33.67 & 27.31 \\
\hline BE-B & 76 & 75 & 78 & 77 & 3 & 3 & 3 & 3 & \begin{tabular}{|l}
191.7 \\
\end{tabular} & 207.5 & 200.8 & 206.7 & 27.00 & 28.56 & 28.83 & 26.81 \\
\hline FAD & 85 & 82 & 90 & 85 & 3 & 3 & 3 & 4 & 263.3 & 322.5 & 320.8 & 314.8 & 32.83 & 40.53 & 41.83 & 38.71 \\
\hline GRIN & 84 & 84 & 81 & 87 & 4 & 3 & 4 & 3 & 206.7 & 215.8 & 212.5 & 208.2 & 31.16 & 35.50 & 36.33 & 31.38 \\
\hline KO-E & 70 & 72 & 69 & 68 & 3 & 3 & 4 & 3 & 210.8 & 252.5 & 215.8 & 225.0 & 27.00 & 24.33 & 25.16 & 26.81 \\
\hline KO-B & 82 & 82 & 79 & 82 & 4 & 3 & 3 & 2 & 194.2 & 187.5 & 172.5 & 178.3 & 28.83 & 26.05 & 29.33 & 31.50 \\
\hline KO-B & 84 & 84 & 87 & 85 & 4 & 3 & 4 & 3 & 232.1 & 220.4 & 226.3 & 218.2 & 25.67 & 26.28 & 27.08 & 27.11 \\
\hline KO-BC1 & 71 & 66 & 66 & 64 & 2 & 3 & 3 & 2 & 187.5 & 199.2 & 187.5 & 194.8 & 25.16 & 21.39 & 23.67 & 24.71 \\
\hline NIEL & 81 & 76 & 77 & 78 & 3 & 3 & 3 & 3 & 234.2 & 248.3 & 239.2 & 234.0 & 37.33 & 34.61 & 33.50 & 32.88 \\
\hline SB-BC1-F & 79 & 75 & 79 & 75 & 3 & 3 & 4 & 3 & 190.0 & 192.5 & 180.0 & 182.5 & 32.33 & 25.45 & 27.67 & 27.16 \\
\hline SB-B & 79 & 77 & 78 & 78 & 2 & 3 & 3 & 2 & 165.0 & 184.2 & 156.6 & 175.8 & 30.50 & 30.61 & 32.00 & 32.33 \\
\hline SB-B & 75 & 70 & 71 & 69 & 2 & 3 & 4 & 2 & 193.3 & 246.7 & 238.3 & 241.5 & 29.17 & 24.89 & 26.67 & 26.05 \\
\hline SB-BC1-F6-1105 & 72 & 72 & 71 & 68 & 3 & 4 & 5 & 4 & 206.7 & 234.2 & 206.7 & 226.8 & 28.83 & 22.78 & 23.83 & 32.26 \\
\hline SEWA & 82 & 82 & 85 & 85 & 3 & 3 & 4 & 2 & 211.7 & 212.5 & 215.0 & 198.3 & 33.33 & 33.17 & 32.33 & 26.50 \\
\hline Mean & 81 & 78 & 80 & 79 & 4 & 3 & 3 & 3 & 235.8 & 256.8 & 252.2 & 248.3 & 31.56 & 31.38 & 33.13 & 33.08 \\
\hline LSD ( & 8 & 7 & 7 & 9 & 1 & 2 & 1 & 2 & 46.2 & 46.8 & 47.5 & 48.9 & 4.33 & 3.50 & 3.61 & 4.01 \\
\hline CV\% & 6 & 7 & 6 & 8 & 23 & 22 & 24 & 23 & 11.5 & 12.6 & 13.9 & 18.9 & 8.10 & 9.40 & 10.25 & 12.54 \\
\hline
\end{tabular}


Table 4. (cont.)

\begin{tabular}{|c|c|c|c|c|c|c|c|c|c|c|c|c|c|c|c|}
\hline \multirow{3}{*}{$\frac{\text { DESIGNATION }}{12 \mathrm{~A} / \mathrm{BE}-\mathrm{BC} 1-\mathrm{F} 6-1048}$} & FA & $\mathrm{KO}$ & SB & SKO & FA & $\mathrm{KO}$ & $\mathrm{SB}$ & SKO & FA & $\mathrm{KO}$ & SB & SKO & 2YEARS & 2018 & 2019 \\
\hline & \multicolumn{4}{|c|}{$\mathrm{PBN} / \mathrm{P}$} & \multicolumn{4}{|c|}{ GN/P } & \multicolumn{4}{|c|}{ NWP } & \multicolumn{3}{|c|}{ YIELD } \\
\hline & 77 & 62 & 60 & 63 & 2378 & 2003 & 2944 & 2772 & 15 & 16 & 15 & 18 & 3447 & 1464 & 5351 \\
\hline 12A/BE-BC1-F6-1105 & 70 & 67 & 65 & 71 & 1805 & 3026 & 3147 & 3215 & 14 & 15 & 14 & 17 & 3262 & 2251 & 4232 \\
\hline 12A/BE-BC1-F6-2070 & 85 & 67 & 81 & 78 & 2990 & 2602 & 2792 & 4091 & 15 & 14 & 14 & 18 & 4618 & 3972 & 5239 \\
\hline 12A/BE-BC1-F6-73 & 77 & 57 & 59 & 62 & 1405 & 1781 & 2350 & 3659 & 14 & 15 & 14 & 16 & 2767 & 1917 & 3582 \\
\hline 12A/BE-BC1-F6-CT-2016 & 83 & 67 & 68 & 60 & 3066 & 2428 & 3260 & 2947 & 14 & 15 & 13 & 18 & 3657 & 1451 & 5775 \\
\hline 12A/KO-BC1-F5-9 & 85 & 58 & 58 & 59 & 2433 & 1709 & 2616 & 3549 & 14 & 14 & 13 & 16 & 3771 & 3038 & 4476 \\
\hline 12A/KO-BC1-F6-1050 & 66 & 55 & 73 & 65 & 2474 & 1473 & 1827 & 9298 & 13 & 13 & 13 & 16 & 2173 & 1784 & 2545 \\
\hline 12A/KO-BC1-F6-1053 & 76 & 70 & 75 & 71 & 3460 & 3283 & 3180 & 3610 & 14 & 14 & 14 & 17 & 3768 & 2676 & 4817 \\
\hline 12A/KO-BC1-F6-1086 & 74 & 60 & 57 & 60 & 2329 & 2224 & 2936 & 2895 & 14 & 13 & 13 & 15 & 3602 & 3320 & 3873 \\
\hline 12A/SB-BC1-F6-1036 & 81 & 72 & 75 & 79 & 3248 & 2432 & 3335 & 3648 & 16 & 14 & 14 & 19 & 4198 & 3305 & 5055 \\
\hline 12A/SB-BC1-F6-1068 & 72 & 59 & 60 & 65 & 3754 & 2599 & 3194 & 5148 & 13 & 13 & 14 & 17 & 3163 & 1825 & 4449 \\
\hline 12A/SB-BC1-F6-1090 & 85 & 55 & 65 & 63 & 3390 & 2437 & 3419 & 4080 & 13 & 14 & 14 & 16 & 3710 & 3003 & 4389 \\
\hline 12A/SB-BC1-F6-1105 & 74 & 55 & 56 & 61 & 3612 & 2083 & 3036 & 3594 & 13 & 13 & 14 & 16 & 4073 & 3737 & 4395 \\
\hline 12B & 54 & 47 & 43 & 46 & 3545 & 1420 & 2097 & 1661 & 13 & 13 & 12 & 17 & 2379 & 2275 & 2478 \\
\hline 216-2AP4-5/BE-BC1-F6-1048 & 83 & 93 & 93 & 93 & 3792 & 3717 & 3706 & 3101 & 15 & 15 & 14 & 19 & 3443 & 2553 & 4298 \\
\hline 216-2AP4-5/BE-BC1-F6-1105 & 61 & 70 & 79 & 74 & 3047 & 2451 & 2720 & 3895 & 13 & 13 & 14 & 16 & 4406 & 3917 & 4876 \\
\hline 216-2AP4-5/BE-BC1-F6 & 74 & 98 & 110 & 94 & 2982 & 2166 & 3388 & 3376 & 15 & 15 & 14 & 19 & 3961 & 2527 & 5337 \\
\hline 216-2AP4-5/BE-BC1-F6-73 & 74 & 85 & 100 & 87 & 1967 & 2449 & 3019 & 3873 & 15 & 14 & 13 & 17 & 3742 & 3273 & 4192 \\
\hline 216-2AP4-5/BE-BC1-F6-CT-2016 & 70 & 89 & 90 & 89 & 2950 & 3155 & 3084 & 3152 & 15 & 16 & 14 & 20 & 3602 & 2699 & 4469 \\
\hline 216-2AP4-5/KO-BC1-F5-9 & 74 & 81 & 78 & 81 & 5582 & 3120 & 3630 & 3535 & 14 & 15 & 12 & 17 & 3443 & 2338 & 4504 \\
\hline 216-2AP4-5/KO-BC1-F6-1050 & 82 & 91 & 89 & 94 & 2497 & 2411 & 3521 & 1431 & 14 & 16 & 13 & 20 & 2458 & 1430 & 3446 \\
\hline 216-2AP4-5/KO-BC1-F6-1053 & 72 & 101 & 103 & 89 & 3648 & 3349 & 4522 & 4885 & 14 & 16 & 14 & 16 & 4624 & 4187 & 5043 \\
\hline 216-2AP4-5/KO-BC1-F6-1086 & 74 & 73 & 88 & 81 & 2627 & 1978 & 3120 & 3207 & 14 & 14 & 13 & 17 & 3920 & 3234 & 4579 \\
\hline 216-2AP4-5/SB-BC1-F6-1036 & 81 & 104 & 95 & 107 & 2829 & 2600 & 3515 & 3126 & 14 & 13 & 13 & 22 & 4116 & 3696 & 4518 \\
\hline 216-2AP4 & 76 & 102 & 104 & 104 & 4796 & 3051 & 4952 & 4482 & 14 & 14 & 14 & 18 & 4068 & 2750 & 5333 \\
\hline $216-2 \mathrm{AP} 4$ & 75 & 88 & 90 & 93 & 1891 & 2623 & 4265 & 3858 & 13 & 14 & 12 & 16 & 3720 & 3506 & 3925 \\
\hline 216-2AP & 76 & 87 & 86 & 80 & 3063 & 2393 & 4119 & 3435 & 14 & 14 & 13 & 16 & 4384 & 3870 & 4877 \\
\hline 216-2AP4-5/SB-BC1-F6 & 74 & 75 & 89 & 86 & 3673 & 2547 & 4405 & 4462 & 13 & 13 & 13 & 18 & 4324 & 3981 & 4653 \\
\hline 216-2BP4-5 & 71 & 95 & 89 & 94 & 1797 & 1651 & 1839 & 1916 & 13 & 16 & 14 & 18 & 2381 & 2031 & 2716 \\
\hline BE-BC1-F6-1048 & 87 & 78 & 85 & 80 & 1566 & 1874 & 1671 & 2333 & 14 & 16 & 14 & 16 & 2311 & 1566 & 3027 \\
\hline BE-BC1-F6-1105 & 71 & 61 & 60 & 61 & 511 & 1331 & 1435 & 2006 & 13 & 12 & 11 & 13 & 2177 & 2008 & 2340 \\
\hline BE-BC1-F6-2070 & 92 & 86 & 89 & 91 & 2263 & 1534 & 2219 & 2338 & 16 & 14 & 13 & 17 & 2860 & 2682 & 3031 \\
\hline BE-BC1-F6-73 & 80 & 82 & 88 & 81 & 1194 & 1712 & 1908 & 1926 & 14 & 15 & 12 & 15 & 2436 & 1970 & 2883 \\
\hline BE-BC1-F6-CT-2016 & 67 & 69 & 70 & 74 & 1074 & 1973 & 1671 & 1811 & 12 & 14 & 13 & 14 & 2400 & 1812 & 2964 \\
\hline FADDA & 60 & 70 & 71 & 73 & 1826 & 2452 & 2264 & 2543 & 12 & 16 & 14 & 19 & 3640 & 2611 & 4628 \\
\hline GRINH & 69 & 76 & 65 & 81 & 1548 & 2622 & 2819 & 2508 & 14 & 15 & 14 & 17 & 2746 & 2673 & 2817 \\
\hline KO-BC & 68 & 62 & 65 & 64 & 881 & 1410 & 1496 & 1893 & 12 & 12 & 12 & 16 & 2212 & 2195 & 2228 \\
\hline KO-BC1-F6-1050 & 72 & 68 & 68 & 70 & 1043 & 1224 & 1499 & 1316 & 13 & 15 & 13 & 15 & 1383 & 1123 & 1632 \\
\hline KO-BC1-F6-1053 & 69 & 86 & 91 & 96 & 2049 & 1824 & 2175 & 2248 & 13 & 14 & 14 & 16 & 2844 & 2294 & 3372 \\
\hline KO-BC1-F6-1086 & 73 & 58 & 63 & 63 & 1617 & 1300 & 1405 & 1979 & 13 & 12 & 10 & 13 & 1959 & 2030 & 1888 \\
\hline NIELENI & 68 & 54 & 55 & 63 & 1638 & 2070 & 1874 & 2291 & 12 & 13 & 12 & 16 & 2537 & 1978 & 3073 \\
\hline SB-BC1-F6-10 & 73 & 94 & 92 & 81 & 1729 & 1522 & 2080 & 1651 & 14 & 13 & 13 & 15 & 2455 & 1948 & 2941 \\
\hline SB-BC1- & 81 & 72 & 74 & 67 & 1218 & 1444 & 2421 & 1162 & 14 & 13 & 12 & 14 & 1733 & 1097 & 2343 \\
\hline SB-BC1-F6-1090 & 53 & 61 & 59 & 62 & 929 & 1808 & 1967 & 2351 & 13 & 13 & 12 & 13 & 2345 & 1889 & 2782 \\
\hline SB-BC1-F6-1105 & 63 & 58 & 60 & 63 & 924 & 1617 & 1451 & 2206 & 13 & 13 & 10 & 13 & 2143 & 1988 & 2299 \\
\hline SEWA & 71 & 54 & 71 & 77 & 1197 & 2097 & 3013 & 1821 & 13 & 15 & 14 & 17 & 2515 & 1772 & 3229 \\
\hline Mean & 74 & 73 & 76 & 76 & 2396 & 2195 & 2767 & 3049 & 14 & 14 & 13 & 17 & 3171 & 2514 & 3802 \\
\hline $\operatorname{LSD}(5 \%)$ & 18 & 18 & 17 & 17 & 1754 & 1528 & 1852 & 1989 & 3 & 3 & 3 & 3 & 1087 & 1121 & 1258 \\
\hline $\mathrm{CV} \%$ & 15 & 14 & 14 & 15 & 41 & 40 & 39 & 38 & 13 & 13 & 14 & 13 & 23 & 25 & 28 \\
\hline
\end{tabular}


Table 4. (cont.)

\begin{tabular}{|c|c|c|c|c|c|c|c|c|}
\hline & FA & $\mathrm{KO}$ & SB & SKO & FA & $\mathrm{KO}$ & SB & SKO \\
\hline DESIGNATION & & $\overline{I R O}$ & & & & & $\mathrm{NC}$ & \\
\hline 12A/BE-BC1-F6-1048 & 13.11 & 26.55 & 50.80 & 20.01 & 11.50 & 10.02 & 6.97 & 12.08 \\
\hline 12A/BE-BC1-F6-1105 & 13.68 & 26.59 & 60.50 & 27.34 & 14.75 & 19.21 & 23.52 & 12.90 \\
\hline 12A/BE-BC1-F6-2070 & 15.64 & 28.74 & 66.24 & 27.08 & 11.31 & 11.65 & 17.57 & 26.79 \\
\hline 12A/BE-BC1-F6-73 & 30.77 & 35.81 & 60.33 & 25.41 & 19.24 & 21.68 & 22.97 & 15.15 \\
\hline 12A/BE-BC1-F6-CT-2016 & 23.37 & 23.38 & 47.08 & 46.75 & 11.67 & 18.19 & 26.09 & 17.92 \\
\hline $12 \mathrm{~A} / \mathrm{KO}-\mathrm{BC} 1-\mathrm{F} 5-9$ & 13.18 & 28.45 & 82.53 & 27.21 & 16.71 & 19.83 & 20.99 & 17.13 \\
\hline 12A/KO-BC1-F6-1050 & 33.53 & 36.30 & 83.38 & 54.42 & 12.83 & 28.71 & 25.13 & 21.31 \\
\hline 12A/KO-BC1-F6- 1053 & 25.51 & 32.06 & 73.64 & 44.63 & 20.37 & 14.39 & 26.58 & 22.67 \\
\hline 12A/KO-BC1-F6-1086 & 25.50 & 29.41 & 59.33 & 26.40 & 13.48 & 22.91 & 25.97 & 16.28 \\
\hline 12A/SB-BC1-F6-1036 & 18.39 & 19.47 & 71.71 & 36.37 & 19.21 & 18.12 & 17.88 & 15.33 \\
\hline 12A/SB-BC1-F6-1068 & 25.63 & 29.85 & 51.91 & 20.39 & 19.95 & 26.04 & 14.67 & 14.09 \\
\hline 12A/SB-BC1-F6-1090 & 28.39 & 31.11 & 70.90 & 37.66 & 16.77 & 15.75 & 18.21 & 22.23 \\
\hline 12A/SB-BC1-F6-1105 & 22.15 & 31.92 & 77.97 & 25.85 & 21.32 & 27.35 & 29.93 & 19.16 \\
\hline 12A/SB-CS-BC1-F6- 1053 & 10.49 & 26.29 & 74.39 & 38.40 & 13.58 & 25.06 & 30.86 & 25.77 \\
\hline 12B & 29.82 & 18.18 & 87.73 & 36.92 & 17.72 & 17.85 & 18.22 & 14.93 \\
\hline 216-2AP4-5/BE-BC1-F6-1048 & 21.75 & 20.79 & 67.81 & 31.44 & 8.14 & 15.49 & 15.96 & 17.75 \\
\hline 216-2AP4-5/BE-BC1-F6-1105 & 18.88 & 31.67 & 69.90 & 39.86 & 9.99 & 14.63 & 19.10 & 14.76 \\
\hline 216-2AP4-5/BE-BC1-F6-2070 & 30.84 & 24.41 & 61.24 & 21.55 & 11.45 & 13.12 & 10.87 & 11.98 \\
\hline 216-2AP4-5/BE-BC1-F6-73 & 16.74 & 28.75 & 64.88 & 40.75 & 16.53 & 13.47 & 21.00 & 17.95 \\
\hline 216-2AP4-5/BE-BC1-F6-CT-2016 & 26.98 & 19.33 & 56.27 & 28.00 & 14.88 & 8.28 & 12.83 & 13.16 \\
\hline 216-2AP4-5/KO-BC1-F5-9 & 8.63 & 23.93 & 49.34 & 36.63 & 11.53 & 19.83 & 17.28 & 17.97 \\
\hline 216-2AP4-5/KO-BC1-F6-1050 & 17.87 & 36.16 & 91.15 & 27.51 & 19.53 & 17.05 & 28.57 & 16.27 \\
\hline 216-2AP4-5/KO-BC1-F6-1053 & 13.65 & 18.36 & 44.63 & 38.55 & 9.60 & 21.98 & 15.36 & 19.00 \\
\hline 216-2AP4-5/KO-BC1-F6-1086 & 17.86 & 21.23 & 46.37 & 21.17 & 21.74 & 9.50 & 22.04 & 19.37 \\
\hline 216-2AP4-5/SB-BC1-F6-1036 & 13.94 & 26.02 & 48.95 & 30.30 & 13.76 & 14.59 & 19.77 & 26.59 \\
\hline 216-2AP4-5/SB-BC1-F6-1053 & 39.88 & 14.17 & 61.66 & 38.35 & 13.52 & 21.70 & 25.36 & 14.43 \\
\hline 216-2AP4-5/SB-BC1-F6-1068 & 10.31 & 14.76 & 61.99 & 25.35 & 19.58 & 13.24 & 17.16 & 15.72 \\
\hline 216-2AP4-5/SB-BC1-F6-1090 & 12.55 & 17.01 & 59.63 & 34.32 & 9.88 & 17.42 & 23.91 & 14.09 \\
\hline $216-2 \mathrm{AP} 4-5 /$ & 23.73 & 23.10 & 58.27 & 22.97 & 11.66 & 18.98 & 15.14 & 11.33 \\
\hline 216-2BP4-5 & 19.70 & 20.60 & 53.02 & 21.20 & 12.58 & 19.47 & 18.30 & 18.79 \\
\hline BE-BC1-F6-1048 & 22.31 & 31.57 & 66.58 & 40.23 & 19.36 & 14.46 & 15.10 & 25.31 \\
\hline BE-BC1-F6-1105 & 18.27 & 17.98 & 42.58 & 12.06 & 16.44 & 17.80 & 17.40 & 12.40 \\
\hline BE-BC1-F6-2070 & 17.36 & 45.40 & 95.14 & 29.11 & 12.65 & 14.21 & 18.07 & 7.68 \\
\hline BE-BC1-F6-73 & 16.55 & 27.75 & 55.91 & 34.31 & 19.77 & 16.31 & 17.95 & 16.69 \\
\hline BE-BC1-F6-CT-2016 & 18.98 & 26.45 & 53.30 & 33.45 & 9.88 & 20.37 & 14.23 & 10.31 \\
\hline FADDA & 17.32 & 27.42 & 43.65 & 32.24 & 16.03 & 11.48 & 21.47 & 23.79 \\
\hline GRINKANYELEWOLO & 14.11 & 16.16 & 44.10 & 29.60 & 12.38 & 12.61 & 18.57 & 15.52 \\
\hline KO-BC1-F5-9 & 32.77 & 36.21 & 72.90 & 21.82 & 17.44 & 6.11 & 11.49 & 8.69 \\
\hline KO-BC1-F6- 1050 & 26.93 & 16.61 & 41.95 & 32.94 & 21.31 & 21.01 & 16.83 & 15.62 \\
\hline KO-BC1-F6- 1053 & 17.70 & 22.49 & 76.84 & 28.79 & 14.21 & 14.54 & 21.98 & 17.72 \\
\hline KO-BC1-F6-1086 & 25.77 & 28.91 & 56.46 & 24.62 & 15.34 & 12.94 & 22.18 & 15.03 \\
\hline NIELENI & 33.71 & 19.83 & 59.27 & 27.50 & 13.40 & 20.04 & 17.89 & 10.49 \\
\hline SB-BC1-F6-1036 & 23.30 & 28.92 & 54.70 & 37.17 & 20.55 & 21.69 & 23.56 & 23.77 \\
\hline SB-BC1-F6-1068 & 16.27 & 42.24 & 52.48 & 30.90 & 21.19 & 15.94 & 15.74 & 15.77 \\
\hline SB-BC1-F6-1090 & 22.87 & 16.20 & 58.27 & 33.05 & 19.17 & 11.72 & 17.63 & 11.02 \\
\hline SB-BC1-F6-1105 & 20.03 & 17.61 & 61.82 & 14.20 & 15.46 & 17.81 & 29.23 & 13.85 \\
\hline SEWA & 13.77 & 15.09 & 41.23 & 25.78 & 11.66 & 15.63 & 10.88 & 20.69 \\
\hline Meal & 20.86 & 25.56 & 61.50 & 30.65 & 15.34 & 17.03 & 19.54 & 16.75 \\
\hline LS & 21.69 & 22.30 & 25.63 & 25.00 & 14.26 & 14.00 & 13.90 & 13.54 \\
\hline CV\% & 22.63 & 20.66 & 21.85 & 23.03 & 30.05 & 28.00 & 27.00 & 23.00 \\
\hline
\end{tabular}


Table 4. (cont.)

\begin{tabular}{|c|c|c|c|c|c|c|c|c|}
\hline & FA & $\mathrm{KO}$ & SB & SKO & FA & $\mathrm{KO}$ & SB & $\mathrm{KO}$ \\
\hline DESIGNATION & \multicolumn{3}{|c|}{ Lysine } & & \multicolumn{4}{|c|}{ Threonine } \\
\hline 12A/KO-BC1-F6-1053 & 2.73 & 3.65 & 3.50 & 4.80 & 2.91 & 2.50 & 2.95 & 3.06 \\
\hline 12A/SB-BC1-F6-1036 & 4.12 & 3.02 & 3.12 & 3.28 & 3.06 & 2.36 & 2.06 & 2.59 \\
\hline 12A/SB-BC1-F6-1090 & 5.61 & 4.08 & 4.61 & 5.13 & 5.94 & 5.94 & 5.94 & 5.90 \\
\hline 216-2AP4-5/KO-BC1-F6-1053 & 4.09 & 4.54 & 3.54 & 3.92 & 3.98 & 3.98 & 2.98 & 3.49 \\
\hline AP4-5/SB-BC1-F6-1036 & 4.95 & 4.63 & 4.40 & 4.95 & 4.58 & 4.34 & 3.58 & 3.8 \\
\hline $216-2 \mathrm{AP}$ & 5.40 & 5.53 & 5.53 & 5.39 & 5.11 & 4.91 & 6.91 & 6.2 \\
\hline FADDA & 0.60 & 0.56 & 0.56 & 0.52 & 1.32 & 1.35 & 1.02 & 0.9 \\
\hline GRINKANYELEW & 0.76 & 0.54 & 0.49 & 0.78 & 1.13 & 1.00 & 1.05 & 1.02 \\
\hline KO-BC1-F6-1053 & 2.99 & 3.05 & 3.15 & 3.10 & 2.36 & 2.05 & 2.35 & 2.39 \\
\hline NIELENI & 1.25 & 1.26 & 1.20 & 1.05 & 1.02 & 0.95 & 0.98 & 1.06 \\
\hline SB-BC1-F & 2.98 & 2.06 & 2.36 & 2.35 & 1.25 & 1.36 & 1.28 & 1.3 \\
\hline SB-BC1 & 4.25 & 4.90 & 5.96 & 5.08 & 6.05 & 6.10 & 6.32 & 6.7 \\
\hline SEWA & 1.05 & 1.10 & 1.32 & 1.23 & 0.63 & 0.59 & 0.89 & 0.98 \\
\hline Mean & 3.14 & 2.99 & 3.06 & 3.20 & 3.02 & 2.88 & 2.95 & $\overline{3.0}$ \\
\hline $\operatorname{LSD}(5 \%)$ & 0.92 & 0.89 & 0.78 & 0.63 & 1.11 & 1.01 & 1.00 & 1.12 \\
\hline $\mathrm{CV} \%$ & 14.33 & 14.00 & 13.90 & 13.87 & 18.66 & 17.56 & 16.50 & 17.00 \\
\hline
\end{tabular}

Genetic Advance as a percentage of Mean for all traits.

The highest values were observed by genetic advance as percentage of mean was recorded by plant height $(31.30 \%)$, primary branch number per panicle $(24.40 \%)$, grain number per panicle $(40.21 \%)$, lysine content $(40.25 \%)$, threonine content $(56.63 \%)$ and grain yield $(41.07 \%)$ (Table 5). These traits above obtained also high values of heritability, indicating that these traits were under additive gene action control. Selection can be improved for these traits.

Table 5.Genetic advance and Genetic advance as a percentage of mean for all traits in this study

\subsection{Correlations Between Traits and Effects of Yield Components on Grain Yield}

\subsubsection{Phenotypic (PCV) and Genotypic (GCV) Coefficient of Correlation}

The coefficients of Genotypic $\left(\mathrm{r}_{\mathrm{g}}\right)$ and Phenotypic $\left(\mathrm{r}_{\mathrm{p}}\right)$ correlation between each trait were estimated and presented in table 6.

\section{$\checkmark$ Genotypic (GCV) coefficient of correlation}

For heading time, a positive and highly significant $(\mathrm{P}<0.01)$ genotypic correlation was observed with panicle length ( $\mathrm{r}_{\mathrm{g}}$ : 0.4881), primary branches number per panicle ( $\left.\mathrm{r}_{\mathrm{g}}: 0.5801\right)$, grain number per panicle ( $\left.\mathrm{r}_{\mathrm{g}}: 0.6037\right)$, number of whorls per panicle $\left(\mathrm{r}_{\mathrm{g}}: 0.7522\right)$ and grain yield (rg: 0.4454).

Positive and highly significant $(\mathrm{P}<0.01)$ genotypic coefficient of correlation was observed for grain quality with primary branches number per panicle ( $\mathrm{rg}_{\mathrm{g}}$.0.6871) while negative correlation was observed with panicle length ( $\left.\mathrm{r}_{\mathrm{g}}:-0.4225\right)$, plant height ( $\mathrm{rg}_{\mathrm{g}}$-0.3204), grain number per panicle ( $\left.r_{g}:-0.4245\right)$, iron content $\quad\left(r_{g}:-0.4197\right)$, zinc content $\left(r_{g}:-0.5053\right)$ and yield $\left(r_{g}:-0.3588\right)$ (Table 6). 
A positive and highly significant $(\mathrm{P}<0.01)$ genotypic coefficient correlation was indicated for plant height with panicle length ( $\left.r_{g}: 0.514\right)$, grain number per panicle $\left(r_{g}: 0.6958\right)$, number of whorls per panicle ( $\left.r_{g}: 0.3235\right)$ and grain yield ( $\left.r_{g}: 0.6068\right)$ (Table 6.).

As indicated in the table 6, higher significant and positive genotypic correlation coefficient was obtained for panicle length with grain number per panicle ( $\mathrm{rg}_{\mathrm{g}}$ 0.7319), number of whorls per panicle ( $\mathrm{r}_{\mathrm{g}}$ : 0.7248), threonine content ( $\left.\mathrm{r}_{\mathrm{g}}: 0.3606\right)$ and grain yield $\left(\mathrm{r}_{\mathrm{g}}: 0.7127\right)$.

The primary branch per panicle recorded a positive and highly significant $(\mathrm{P}<0.01)$ genotypic correlation coefficient with grain number per panicle ( $\mathrm{r}_{\mathrm{g}}$ : 0.4168), number of whorls per panicle ( $\mathrm{rg}$ : 0.6297) and grain yield ( $\mathrm{rg}_{\mathrm{g}}$ 0.3568) while a negative genotypic correlation coefficient was indicated with threonine content ( $\mathrm{rg}:$-0.3996) (Table 6).

The grain number per panicle recorded a positive and highly significant $(\mathrm{P}<0.01)$ genotypic correlation coefficient with number of whorls per panicle $\left(\mathrm{r}_{\mathrm{g}}: 0.6246\right)$ and grain yield $\left(\mathrm{r}_{\mathrm{g}}: 0.6653\right)$ (Table 6.).

Higher significant and positive genotypic correlation coefficient was obtained for number of whorls per panicle with grain yield $\left(\mathrm{r}_{\mathrm{g}}: 0.7128\right)$. The negative genotypic correlation coefficient was observed with the threonine content ( $\left.\mathrm{r}_{\mathrm{g}}:-0.5096\right)$.

The iron content recorded a positive and highly significant $(\mathrm{P}<0.01)$ genotypic correlation coefficient with zinc content ( $\mathrm{rg}_{\mathrm{g}}$ 0.378) (Table 6.).

The lysine content recorded a positive and highly significant $(\mathrm{P}<0.01)$ genotypic correlation coefficient with threonine content (rg: 1.021) (table 6).

\section{$\checkmark$ Phenotypic (PCV) coefficient of correlation}

Table 6. indicates for heading time a positive and highly significant $(\mathrm{P}<0.01)$ phenotypic correlation with plant height $\left(r_{p}\right.$ : 0.2055), panicle length $\left(r_{p}: 0.3551\right)$, primary branches number per panicle ( $\left.\mathrm{r}_{\mathrm{p}}: 4909\right)$, grain number per panicle $\left(\mathrm{r}_{\mathrm{p}}: 0.3815\right)$, number of whorls per panicle $\left(\mathrm{r}_{\mathrm{p}}\right.$ : $0.4968)$ and grain yield ( $\left.\mathrm{r}_{\mathrm{p}}: 0.3336\right)$.

Positive and significant $(\mathrm{P}<0.01)$ phenotypic coefficient correlation was observed for grain quality with primary branches number per panicle $\left(\mathrm{r}_{\mathrm{p}}\right.$ : 0.1795$)$ while negative correlation was also observed with plant length $\left(\mathrm{r}_{\mathrm{p}}:-0.216\right)$, iron content $\left(\mathrm{r}_{\mathrm{p}}:-0.1923\right)$ and zinc content $\left(\mathrm{r}_{\mathrm{p}}:-0.1547\right)$ (Table 6).

A positive and highly significant $(\mathrm{P}<0.01)$ phenotypic coefficient correlation was indicated for plant height with panicle length $\left(r_{p}: 0.514\right)$, grain number per panicle $\left(r_{p}: 0.6958\right)$, number of whorls per panicle $\left(\mathrm{r}_{\mathrm{p}}: 0.3235\right)$ and grain yield $\left(\mathrm{r}_{\mathrm{p}}: 0.6068\right)$ (table 6$)$.

As indicated in the table 6 , higher significant and positive phenotypic correlation coefficient was obtained for panicle length with grain number per panicle ( $\left.r_{p}: 0.4945\right)$, number of whorls per panicle ( $\left.\mathrm{r}_{\mathrm{p}}: 0.5037\right)$ and grain yield $\left(\mathrm{r}_{\mathrm{p}}: 0.4822\right)$.

The primary branch per panicle recorded a positive and highly significant $(\mathrm{P}<0.01)$ phenotypic correlation coefficient with grain number per panicle $\left(r_{p}: 0.2409\right)$, number of whorls per panicle 
$\left(\mathrm{r}_{\mathrm{p}}: 0.4343\right)$ and grain yield $\left(\mathrm{r}_{\mathrm{p}}: 0.2681\right)$ (Table 6).

The grain number per panicle recorded a positive and highly significant $(\mathrm{P}<0.01)$ phenotypic correlation coefficient with number of whorls per panicle $\left(r_{p}: 0.3052\right)$ and grain yield $\left(r_{g}: 0.5175\right)$ (Table 6).

As indicated in the table 6 , higher significant and positive phenotypic correlation coefficient was obtained for number of whorls per panicle with grain yield $\left(r_{p}: 0.3766\right)$.

The iron content recorded a positive and highly significant $(\mathrm{P}<0.01)$ phenotypic correlation coefficient with zinc content ( $\mathrm{r}_{\mathrm{p}}$ : 0.2367) (Table 6).

The lysine content recorded a positive and highly significant $(\mathrm{P}<0.01)$ phenotypic correlation coefficient with threonine content $\left(\mathrm{r}_{\mathrm{p}}: 0.2157\right)$ and grain yield $\left(\mathrm{r}_{\mathrm{p}}: 0.1812\right)$ (Table 6).

Table 6. Estimation of genotype (above diagonal) and phenotype (below diagonal) coefficient of correlation for 12 traits

\begin{tabular}{|c|c|c|c|c|c|c|c|c|c|c|c|c|}
\hline & Cycle & Gain quality & Plant height & t Panicle length & PBN/P & $\mathrm{GN} / \mathrm{P}$ & NWP & Iron & Zinc & Lysine & Threonine & Yield \\
\hline CYCLE & $1 * *$ & $0.0483 \mathrm{NS}$ & $0.2388 \mathrm{NS}$ & $0.4881 * *$ & $0.5801 * *$ & $0.6037^{* *}$ & $0.7522 * *$ & $-0.1472 \mathrm{NS}$ & $0.0557 \mathrm{NS}$ & $0.0881 \mathrm{NS}$ & $-0.0897 \mathrm{NS}$ & 0.4454 ** \\
\hline Gain quality & $-0.024 \mathrm{NS}$ & $1 * *$ & $-0.3204 *$ & $-0.4225 * *$ & $0.6871 * *$ & $-0.4245 *$ & $0.0146 \mathrm{NS}$ & $-0.4197 * *$ & $-0.5053 * *$ & *0.013 NS & $0.0626 \mathrm{NS}$ & $-0.3588 *$ \\
\hline plant height & $0.2055 * *$ & -0.1044 NS & $1 * *$ & $0.514^{* *}$ & $0.1609 \mathrm{NS}$ & $0.6958 * *$ & $0.3235 *$ & $0.106 \mathrm{NS}$ & $0.2882 \mathrm{NS}$ & $0.1093 \mathrm{NS}$ & $0.0811 \mathrm{NS}$ & 0.6068 ** \\
\hline Panicle lenght & $0.3551 * *$ & $-0.216 * *$ & $0.4629 * *$ & $1 * *$ & $0.097 \mathrm{NS}$ & $0.7319 * *$ & $0.7248 * *$ & $0.1664 \mathrm{NS}$ & $0.271 \mathrm{NS}$ & $0.0581 \mathrm{NS}$ & $0.3606 *$ & 0.7127 ** \\
\hline $\mathrm{PBN} / \mathrm{P}$ & 0.4909 ** & $0.1795 *$ & $0.1083 \mathrm{NS}$ & $0.0296 \mathrm{NS}$ & $1 * *$ & $0.4168 *$ & $0.6297 * *$ & $-0.0504 \mathrm{NS}$ & $-0.1759 \mathrm{NS}$ & S $0.1428 \mathrm{NS}$ & -0.3996 ** & $0.3568 *$ \\
\hline GN/P & 0.3815 ** & $0.0362 \mathrm{NS}$ & $0.5017 * *$ & $0.4945 * *$ & $0.2409 * *$ & $1 * *$ & $0.6246 * *$ & $0.2465 \mathrm{NS}$ & $0.2609 \mathrm{NS}$ & $0.1835 \mathrm{NS}$ & $-0.1056 \mathrm{NS}$ & 0.6653 ** \\
\hline $\mathrm{NW} / \mathrm{P}$ & 0.4968 ** & $-0.0831 \mathrm{NS}$ & $0.2134 * *$ & $0.5037 * *$ & $0.4343 * *$ & $0.3052 * *$ & $1 * *$ & $0.149 \mathrm{NS}$ & $-0.2062 \mathrm{~N}$ & Is $5 \mathrm{e}-04 \mathrm{NS}$ & $-0.5096^{* *}$ & 0.7128 ** \\
\hline Iron & $-0.0511 \mathrm{NS}$ & $-0.1923 * *$ & $0.0807 \mathrm{NS}$ & $0.0895 \mathrm{NS}$ & $-0.0595 \mathrm{NS}$ & $0.0862 \mathrm{NS}$ & $0.0126 \mathrm{NS}$ & $1 * *$ & $0.378 * *$ & $-0.0373 \mathrm{NS}$ & $0.0773 \mathrm{~N}$ & $0.231 \mathrm{NS}$ \\
\hline Zinc & $0.0587 \mathrm{NS}$ & $-0.1547 *$ & $0.107 \mathrm{NS}$ & $0.1101 \mathrm{NS}$ & $-0.0329 \mathrm{NS}$ & $0.0036 \mathrm{NS}$ & $0.0219 \mathrm{NS}$ & $0.2367 * *$ & $1 * *$ & $0.133 \mathrm{NS}$ & $0.0505 \mathrm{NS}$ & $0.2218 \mathrm{NS}$ \\
\hline Lysine & $0.0764 \mathrm{NS}$ & $0.0179 \mathrm{NS}$ & $0.1069 \mathrm{NS}$ & $0.0468 \mathrm{NS}$ & $0.1206 \mathrm{NS}$ & $0.1308 \mathrm{~N}$ & ؛ $0.0098 \mathrm{NS}$ & $-0.0127 \mathrm{NS}$ & $0.0676 \mathrm{Ns}$ & \& $1^{* *}$ & 1.021 ** & $0.2157 \mathrm{NS}$ \\
\hline Threonine & $-0.0081 \mathrm{NS}$ & $0.0163 \mathrm{NS}$ & $0.0061 \mathrm{NS}$ & $0.0083 \mathrm{NS}$ & $-0.0609 \mathrm{NS}$ & $-0.0277 \mathrm{NS}$ & S-0.0611 NS & $-0.0258 \mathrm{NS}$ & $-0.0895 \mathrm{NS}$ & S $0.2157 * *$ & $1 * *$ & $-0.0911 \mathrm{NS}$ \\
\hline Yield & 0.3336 ** & $0.0021 \mathrm{NS}$ & 0.4716 ** & $0.4822 * *$ & $0.2681 * *$ & $0.5175 * *$ & 0.3766 ** & $-0.0301 \mathrm{NS}$ & $-0.0135 \mathrm{~N}$ & $0.1812 *$ & $-0.0034 \mathrm{NS}$ & $1 * *$ \\
\hline
\end{tabular}

*Significant at 5\% level: 0.05 and ** significant at 1\% level :0.01

\subsubsection{Path Coefficient Analysis}

The heading time at phenotypic $(\mathrm{P})$ correlation level, presented positive $(0.013)$ direct effect on grain yield (Table 7). It had also exhibited positive indirect effect on grain yield through plant height (0.04), primary branches number per panicle (0.05), number of whorls per panicle (0.047), iron content (0.003), lysine content (0.008) and threonine content (0.0001) while it presented indirectly negative effect on grain yield through grain quality $(-0.0008)$ and zinc content (-0.003) (Table 7).

The cycle at genotypic $(\mathrm{G})$ correlation level, the path coefficient analysis showed not direct effect on grain yield (Table 7). Positive indirect effect on grain yield was observed with grain quality (0.01), iron content (0.006), zinc content (0.01), lysine content (0.03) and threonine content (0.01). It also had negative indirect effect on grain yield through panicle length (-0.009) (Table 7).

There was a positive (0.03) direct effect for grain quality on grain yield at phenotypic correlation (Table 7). It showed positive indirect effect on grain yield with primary branches 
number per panicle $(0.01)$, grain number per panicle $(0.008)$, iron content $(0.01)$, lysine content (0.007) and lysine content (0.001) (Table 7) while negative indirect effect was observed on grain yield through plant height (-0.02), panicle length $(-0.04)$, number of whorls per panicle $(-0.007)$, threonine content $(-0.0002)$ and cycle $(0.0032)$.

At genotypic correlation for grain quality, there was not a direct effect on grain yield $(0.21)$ (Table 7). It showed positive indirect effect on grain yield with panicle length (0.0078), number of whorls per panicle (0.01), iron content (0.01), lysine content (0.005) and threonine content (0.01). Grain quality showed negative influence on grain yield through grain number per panicle (-0.04) and cycle (-0.01).

Plant height at phenotypic correlation showed no direct effect on grain yield (0.222) (Table 7). Its influence on grain yield was observed to be in positive indirect direction through cycle (0.002), primary branches number per panicle (0.01), number of whorls per panicle (0.02) and lysine content (0.011) while its influence on grain yield was shown to be in negative indirect direction with grain quality $(-0.003)$, iron content $(-0.005)$, zinc content $(-0.005)$ and threonine content (-0.0001) (Table 7).

The genotypic correlation for plant height shown also no direct effect on grain yield (0.30) (Table 7). There was a positive indirect effect for plant height on grain yield through lysine content (0.04) while negative indirect effect was observed for plant height on grain yield with panicle length (-0.009), iron content (-0.004) and threonine content (-0.01) (Table 7).

Panicle length at phenotypic correlation showed direct effect on grain yield (0.0226) (Table 7). Its influence on grain yield was observed to be in positive indirect direction through cycle (0.004), primary branches number per panicle (0.003), number of whorls per panicle (0.04) and lysine content (0.005) while its influence on grain yield was shown to be in negative indirect direction with grain quality $(-0.007)$, iron content $(-0.005)$, zinc content $(-0.005)$ and threonine content (-0.00015) (Table 7).

At genotypic correlation for panicle length, there was negative direct effect on grain yield (-0.01) (Table 6.5). It showed positive indirect effect on grain yield with lysine content (0.02). Panicle length showed negative influence on grain yield through primary branches number per panicle (-0.04) and iron content (-0.007) (Table 7).

Primary branches number per panicle had direct effect of 0.011 towards grain yield (Table 7). It had positive indirect effect on grain yield through cycle (0.006), grain quality (0.005), plant height (0.02), panicle length (0.006), grain number per panicle $(0.05)$, number of whorls per panicle (0.04), iron content (0.003), zinc content $(0.001)$, lysine content $(0.01)$, threonine content (0.001) (Table 7) at phenotypic correlation level.

Genotypic correlation for Primary branches number per panicle shown no direct effect toward grain yield (Table 7). Its influence on grain yield was observed to be in positive indirect direction through plant height (0.004), grain number per panicle $(0.04)$ and iron content $(0.002)$ (Table 7). while its influence on grain yield was found to be in negative indirect effect with panicle length -0.001 (Table 7). 
Grain number per panicle had direct effect of 0.0222 towards grain yield (Table 7). It had positive indirect effect on grain yield through cycle (0.005), grain quality (0.001), plant height (0.02), primary branch number per panicle $(0.02)$, number of whorls per panicle $(0.02)$, lysine content $(0.01)$ and threonine content $(0.0005)$ while it obtained negative indirect effect on grain yield with iron content $(-0.005)$ and zinc content $(-0.0001)$ (Table 7$)$ at phenotypic correlation level.

Genotypic correlation for grain number per panicle shown no direct effect toward grain yield (Table 7). Its influence on grain yield was observed to be in positive indirect direction through threonine content (0.02) (Table 7) and then its influence on grain yield was found to be in negative indirect effect with panicle length (-0.001) and iron content (-0.01) (Table 7).

There was direct effect 0.009 for number of whorls per panicle towards grain yield at phenotypic correlation (Table 7). It shown positive indirect effect on grain yield with cycle 0.006 , plant height 0.04 , primary branches number per panicle $(0.04)$, iron content $(0.01)$, lysine content (0.001) and threonine content (0.001) (Table 6.5) while negative indirect effect was observed on grain yield through grain quality $(-0.002)$, iron content $(-0.0007)$ and zinc content $(-0.001)$ (Table 7).

At genotypic correlation for number of whorls per panicle, there was not a direct effect on grain yield (1.02) (Table 7). It showed positive indirect effect on grain yield with grain quality 0.003 and lysine content (0.0002). Number of whorls per panicle shown negative influence on grain yield through panicle length (-0.01) and iron content -0.006 (Table 7).

Iron content at phenotypic correlation showed no direct effect on grain yield (-0.06) (Table 7). Its influence on grain yield was observed to be in positive indirect direction through plant height (0.0.1), panicle length (0.02), grain number per panicle $(0.01)$ and threonine content (0.0004) while its influence on grain yield was shown to be in negative indirect direction with cycle (-0.0006), grain quality ( -0.006), primary branch per panicle $(-0.006)$, zinc content $(-0.01)$ and lysine content $(-0.001)$ (Table 7$)$.

At genotypic correlation level for iron content, there was negative direct effect on grain yield $(-0.04)$ (Table 7). It showed positive indirect effect on grain yield with cycle (0.04), plant height $(0.03)$, lysine content $(0.02)$, primary branch per panicle $(0.02)$ and grain number per panicle (0.02). Iron content shown negative influence on grain yield through panicle length $(-0.003)$, lysine content (-0.01) and threonine content (-0.01) (Table 7).

The zinc content at phenotypic $(\mathrm{P})$ correlation level, presented negative $(-0.05)$ direct effect on grain yield (Table 7). It had also exhibited positive indirect effect on grain yield through cycle (0.0007), plant height (0.02), panicle length (0.02), grain number per panicle (0.0008). number of whorls per panicle (0.002), lysine content (0.007) and threonine content $(0.0001)$ while it presented indirectly negative effect on grain yield through grain quality (-0.005), primary branch per panicle (-0.003) and iron content (-0.01) (Table 7).

The zinc content at genotypic $(\mathrm{G})$ correlation level, the path coefficient analysis showed not direct effect on grain yield (Table 7). Positive indirect effect on grain yield was observed with grain number per panicle (0.02) and lysine content $(0.05)$. It also had negative indirect effect on 
grain yield through cycle (-0.01), panicle length (-0.005), iron content (-0.01) ant threonine content (-0.01) (Table 7).

Lysine content had not directed effect of 0.222 towards grain yield (Table 7). It had positive indirect effect on grain yield through cycle (0.001), grain quality (0.00051), plant height (0.02), panicle length $(0.01)$, primary branch number per panicle $(0.01)$, grain number per panicle (0.02), number of whorls per panicle (0.0009), iron content $(0.0007)$ and threonine content $(0.0005)$ while it obtained negative indirect effect on grain yield with zinc content $(-0.001)$ and threonine content (-0.003) (Table 7) at phenotypic correlation level.

Genotypic correlation for lysine content shown no direct effect toward grain yield (Table 7). Its influence on grain yield was observed to be in positive indirect direction through grain quality (0.002), plant height (0.03), grain number per panicle $(0.01)$, number of whorls per panicle (0.0005), iron content (0.001) and zinc content (0.04) (Table 7) and then its influence on grain yield was found to be in negative indirect effect with cycle ( -0.0.2) and panicle length -0.001 (Table 7).

The threonine content at phenotypic (P) correlation level, presented negative (-0.01) direct effect on grain yield (Table 6.5). It had also exhibited positive indirect effect on grain yield through grain quality $(0.0005)$, plant height $(0.001)$, panicle length $(0.001)$, iron content (0.001), zinc content (0.004) and lysine content (0.02) while it presented indirectly negative effect on grain yield through cycle $(-0.0001)$, primary branch per panicle $(-0.006)$, grain number per panicle (-0.006) and number of whorls per panicle -0.005 (Table 7).

The threonine content at genotypic $(\mathrm{G})$ correlation level, the path coefficient analysis showed not direct effect on grain yield (Table 7). Positive indirect effect on grain yield was observed with cycle (0.02), plant height (0.02) and zinc content (0.01). It also had negative indirect effect on grain yield through grain quality $(-0.01)$, panicle length $(-0.006)$, grain number per panicle $(-0.01)$ and iron content -0.003 (Table 7). 
Table 7. Estimation of phenotype (P) and genotype (G) direct (diagonal and bold) and indirect (off diagonal) effects of 11 traits on grain yield

\begin{tabular}{|c|c|c|c|c|c|c|c|c|c|c|c|c|}
\hline & & Cycle & Grain quality & Plant height & Panicle length & $\mathrm{PBN} / \mathrm{P}$ & GN/P & NW/P & Iron & Zinc & Lysine & Threonine \\
\hline \multirow{2}{*}{ Cycle } & $\mathrm{P}$ & 0.01322 & -0.00080 & 0.04570 & 0.08053 & 0.05423 & 0.08502 & 0.04710 & 0.00317 & -0.00302 & 0.00829 & 0.00015 \\
\hline & G & -0.27840 & 0.01046 & 0.07230 & -0.00911 & -0.26285 & & & & 0.01 & 0.03 & 0.01937 \\
\hline \multirow{2}{*}{ Grain quality } & $\mathrm{P}$ & .00032 & & & & & & & & & & \\
\hline & G & -0.01345 & 0.21660 & -0.09701 & 0.00789 & -0.3 & -0.0 & 50.0 & 0.0 & -0.1 & 0.00554 & 0.01353 \\
\hline \multirow{2}{*}{ Plant height } & $\mathrm{P}$ & 0.00272 & -0.00345 & 0.22238 & 0.10497 & 0.01 & 0.1 & 0.0 & & -0.0 & 0.01159 & -0.00011 \\
\hline & G & -0.06647 & -0.06940 & 0.30279 & -0.00959 & -0.0 & 0.0 & & & 0.0 & 0.0 & -0.01751 \\
\hline \multirow{2}{*}{ Panicle lenght } & $\mathrm{P}$ & 0.00 & & & & 0.0 & & & & & & -0. \\
\hline & G & -0.1 & & & & -0.04395 & 0.0 & 0.7 & -0. & 0.0 & 0.0 & 789 \\
\hline \multirow{2}{*}{$\mathrm{PBN} / \mathrm{P}$} & $\mathrm{P}$ & 0.00649 & 0.00593 & 0.02408 & 0.00671 & 0.0110 & 0.0 & 0.0 & 0.0 & 0.0 & 0.0 & 0.00109 \\
\hline & $\mathrm{G}$ & -0.16149 & 0.14882 & 0.04873 & -0.00181 & -0.45315 & 0.0 & $26^{\prime}$ & 0.0 & -0.0 & 0.06071 & 0.08632 \\
\hline \multirow{2}{*}{ GN/P } & $\mathrm{P}$ & 0.00504 & 0.00120 & 0.11157 & 0.11214 & 0.02661 & 0.0223 & 0.02894 & & -0.0 & 0.01418 & 0.00050 \\
\hline & $\mathrm{G}$ & -0.16806 & & & & -0.18889 & 0.09696 & $0.64112^{\prime}$ & -0.0 & 0.08 & 0.07801 & 0.02282 \\
\hline \multirow{2}{*}{$\mathrm{NW} / \mathrm{P}$} & $\mathrm{P}$ & 0.0 & & & & 0.04 & 0.0 & 0.0 & & -0. & 0.0 & \\
\hline & G & -0.2 & & 0.0 & & -0.28 & 0.0 & 1.0 & -0. & -0.0 & 0.00022 & 0.11008 \\
\hline \multirow{2}{*}{ Iron } & $\mathrm{P}$ & -0.00068 & -0.00635 & 0.01795 & 0.02030 & & 0.0 & 0.0 & -0. & -0.0 & -0.00138 & 0.00046 \\
\hline & $\mathrm{G}$ & 0.04098 & -0.09090 & 0.03210 & -0.00311 & 0.02282 & 0.02 & 0.1 & -0. & 0.12 & -0.01587 & -0.01669 \\
\hline \multirow{2}{*}{ Zinc } & $\mathrm{P}$ & 0.00 & & & & -0.0 & 0.0 & 0.0 & & -0.0 & 10.0 & 0.00161 \\
\hline & G & -0.0 & & & & 0.0 & & -0.2 & & 0.3 & 0.05652 & -0.01091 \\
\hline \multirow{2}{*}{ Lysine } & $\mathrm{P}$ & 0.00101 & 0.00058 & 0.02377 & 0.01059 & 0.0 & 5 & 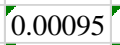 & 079 & -0.00347 & 0.10838 & -0.00387 \\
\hline & G & -0.02451 & 0.00282 & 0.03310 & -0.00109 & -0.06471 & 0.0 & 0.00053 & 0.00167 & 0.04553 & 0.42514 & -0.22056 \\
\hline \multirow{2}{*}{ Threonine } & $\mathrm{P}$ & -0.00011 & & & 0.00188 & & & & 0.0 & 0.00460 & 0.02338 & -0.01796 \\
\hline & $\mathrm{G}$ & 0.02497 & -0.01357 & 0.02454 & -0.00673 & 0.18107 & -0.01024 & -0.52302 & -0.00345 & 0.01730 & 0.43407 & -0.21601 \\
\hline
\end{tabular}

Residual effect of $(\mathrm{P}): \quad 0.5784 \quad$ and Residual effect of $(\mathrm{G}): 0.2198$

\section{Discussion}

Notable differences between hybrids and controls were observed in all study environments for heading. This situation can be explained by the fact that the hybrids are the result of crosses between early parents and intermediate parents which had different degrees of photosensitivity. Such hybrids do not necessarily have the same reaction when it comes to their heading date. The parent's earliness genes show up in hybrids, and results indicated that some hybrids are earlier than most the parents used in combinations. This result also presents an opportunity for breeding programs to identify hybrids for different agro-ecologies going to the Sub-Sahel to the Guinea zones.

Significant variability was observed for the plant height in all environments. In environments with a high amount of rainfall, the treatments are of a fairly large height resulting in an increase in the height of the plants compared to other environments. These results indicate that hybrids tend to produce plants that are closer in height to the parents used in the crosses. This offers an opportunity to select short to medium height for the intensification but allows farmers who are looking for tall plants to use later stover for garden and other needs. However, it should be noted that tall hybrids are not recommended due to their susceptibility to lodging which can cause yield losses. It is therefore important to note that hybrids of reduced height, resistant to lodging, are the most recommended for intensification of sorghum cultivation.

In general, hybrids were more productive than varieties (controls and parents) across all 4 
environments confirming the performance of hybrids over open pollinated varieties. Similar results have been obtained by several authors (Rattunde et al (2013); Kante et al (2017).

Differences were observed between treatments in all locations for grain quality, panicle length, primary branches per panicle, grain number per panicle, iron, lysine, threonine content and number of whorls per panicle. The overall treatment averages also vary by environment. This difference could be explained by the genetic background of the hybrid's parents. Our results are in agreement with those found by Fayeun et al. 2012, Arunkumar 2013, Menezes et al. 2015, Eniola 2019; who have shown significant variability in sorghum hybrids.

Important genetic advances as per cent of mean was observed for plant height, primary branch number per panicle, grain number per panicle, lysine content, threonine content and grain yield indicating that these traits were in the control of additive gene action. It means that selection can be made for these traits. This result is in accordance with those found by Godbharle et al. (2010) for plant height and number of primary branches. Moderate genetic advance as per cent of mean was obtained by Cycle, panicle length, iron and zinc content obtained, indicating that, these characters are controlled by both additive and non-additive gene actions.

Study of correlation allowed us to understand the relationship between two or more traits simultaneously in theoretical and practical value since selection is usually made based on various traits explained. The genetic correlation coefficients were high for some traits in this study, therefore a strong heritability existed among traits as explained by Johnson et al. (1955). This indicated that the selection can be made from fews traits only. Small values of the genotypic correlation coefficient found may slow the progress of selection. Negative values of genotypic coefficient correlation were identified by some of the traits indicating that selection for some of traits would affect each other in the opposite direction as earlier suggested by Bello et al. (2001).

Improvement of grain yield can be achieved by a correlation coefficient, which helps to determine the direction of selection with the number of traits. It is therefore very important for plant breeders to discover which traits are correlated with yield and also how they are associated with themselves.

Positive significant association with some traits for all studied characters on grain yield were found in this study at genotypic and phenotypic levels, indicating that selection for those traits improves simultaneously grain yield. Negative significant associations were obtained at genotypic and phenotypic levels on grain yield for all studied traits which means selection of those traits makes it impossible to achieve at the same time improvement of those traits along with each other's. Our results are in agreement with many results found by various scientists. Some outcomes are in opposite for those obtained by workers.

Path coefficient analysis measures the direct influence of one variable upon the other and permits the separation of correlation coefficient into components of direct and indirect effects. Partitioning of total correlation into direct and indirect effects provides actual information on 
the contribution of characters and thus forms the basis for selection to improve yield. Hence genotypic correlations were partitioned into direct and indirect effects to know the relative importance of the components.

This study, it found that the cycle, grain quality, panicle length, grain number per panicle, primary branch and a number of whorls per panicle had a positive and direct effects on grain yield. These traits should be considered at the same time when developing criteria for grain yield improvement in sorghum. Our outcomes are in accordance with several works found by (Jindal \& Gill 1984, Singh \& Govila 1989, Bidinger et al. 1993, Eniola 2019). It is inferred from correlation and path analysis these traits recorded significant positive correlation co-efficient and also had a high positive direct effect that might be regarded as the primes characters. This indicates that the traits are the most important influencing the grain yield. Thus, selection for these traits is important to attaining higher grain yield in sorghum. Its indirect effect through cycle, grain quality, panicle length, grain number per panicle, primary branch and number of whorls per panicle have been high among all traits that contributed significantly to grain yield.

\section{Conclusion}

The evaluation of fortified hybrids compared to parents and checks hybrids yielded interesting results. This study provided a better understanding of the performance of fortified hybrids to develop hybrids containing amino acids and mineral elements content that meet consumer criteria. Thus, the different origins of the genetic material to be used in the development of hybrids is important to consider. The agro-ecological zone targeted in the development of hybrids will play a crucial factor for in large-scale success of hybrids.

For all the characters studied, the fortified hybrids 216-2AP4-5 / KO-BC1-F6-1053, 216-2AP4-5 / BE-BC1-F6-1105，216-2AP4-5 / SB-BC1-F6-1090, 216-2AP4-5 / SB-BC1-F6-1105, 12A / SB-BC1-F6-1036, 216-2AP4-5 / SB-BC1-F6-1036, 12A / SB-BC1-F6-1105 and 216 -2AP4-5 / SB-BC1-F6-1053 had a grain yield over 4 tons and better components of yield and then which combined with a high amino acid and mineral content. These hybrids can be further evaluated in collaboration with farmers to identify the most stable across different conditions and social needs for their registration in the seed catalog.

Plant height, primary branch number per panicle, grain number per panicle, lysine, threonine content and grain yield had high genetic advance as percentage of mean.

Regarding, correlations for grain yield and its components and to understand their direct and indirect effects on grain yield. For both a phenotypic and genotypic levels, a significant correlation on grain yield through plant height, panicle length, primary branch per panicle, grain number per panicle and number of whorls per panicle were found. The inheritance of association among traits at genotypic correlation level on grain yield, indicating that selection will be effective for improvement of grain yield of the genotypes.

Based on the path analysis, positive and significant direct and indirect effects of correlation were observed in this work for cycle, grain quality, panicle length, primary branch per panicle, 
grain number per panicle and number of whorls per panicle at the phenotypic level, which indicates selection would be effective for these traits in the improvement of grain yield in development of hybrid sorghum.

\section{Acknowledgments}

This work has been accomplished with the financial support of BHEARD (Borlaug Higher Education for agricultural Research and development), and the McKnight Foundation trough the Networking4Seed project coordinated by ICRISAT. We would like to thank the "Institut d'Economie Rural" (IER) and ICRISAT for providing plant material used in this study.

\section{References}

Arunkumar, B. (2013). Genetic variability, character association and path Analysis studies in sorghum (Sorghum bicolor L .Moench). Agricultural Research Station, Raddewadgi, Gulabarga, (Karnataka). International Quartely Journal of Life Sciences, 8(4), 1485-1488. ID 54966330.

Beil, G. M., \& Atkins, R. E. (1967). Estimates of general and specific combining ability in F1 hybrids for grain yield and its components in grain sorghum, Sorghum vulgare Pers. Crop Science, 7, 225-228. https://doi.org/10.2135/cropsci1967.0011183X000700030016x

Bello, D., Kadams A. M., \& Simon, S. Y. (2001). Correlation and Path Coefficient analysis of grain yield and its components in Sorghum. Nigerian Journal of Tropical Agriculture, 3, 4-9.

Berenji, J. (1988). Evaluation of combining ability and heterosis and analysis of yield components in grain sorghum. Bilten za Hmelj, Sirak i Lekovito Bilje, 20, 56-57.

Bidinger, F. R., Alagarswamy, G., \& Rai, K. N. (1993). Use of grain number components as selection criteria in pearl millet. Crop Improvement, 20, 21-26.

Can, N. D., Nakamura, S., \& Yoshida, T. (1997). Combining ability and Genotype x Environmental interaction in early maturing grain sorghum for summer seeding. Japanese Journal of Crop Science, 66(4), 698-705. https://doi.org/10.1626/jcs.66.698

Deepalakshmi, A. J., \& Ganesamurthy, K. (2007). Studies on genetic variability and character association in kharif sorghum [Sorghum bicolor (L.) Monech]. Indian Journal of Agricultural Research, 41(3), 177-182.

Dewey, D. R., \& Lu, K. H. (1959). A correlation and path coefficient analysis of Components of Crested Wheatgrass Seed Production. Agronomy Journal, 51, 515-518. https://doi.org/10.2134/agronj1959.00021962005100090002x

DNA-Mali. (2020). Evolution des superficies et des productions du sorgho au Mali. Rapport bilan campagne 2019/2020.

Eniola, A. O. (2019). Evaluation of Grain Yield and Yield Components of Sorghum (Sorghum bicolor (L.) Moench.) Hybrids in Akure South West Nigeria. (M. Tech. (Agric.) Thesis). Federal University of Technology, Akure, Nigeria.

Falconer, D. S. (1989). Introduction to quantitative genetics. 3rd ed. Longman Scientific and 
Technical CO., Essex, England.

FAO. (2019). The State of Food Insecurity in the World: High Food Prices and Food Security Threats and Opportunities. FAO, Rome, Italy.

FAOSTAT, (2018). Food and Agriculture Organization of the United Nations Cropping Database (http://faostat3.fao.org/home/index.html

Fayeun, L. S., Odiyi, A. C., Makinde, S. C. O., \& Aiyelari, O. P. (2012). Genetic Variability and Correlation Studies in the Fluted Pumpkin (Telfairia occidentalis Hook. F.). Journal of Plant Breeding and Crop Science, 4(10), 156-160. https://doi.org/10.5897/JPBCS12.011

Godbharle, A. R., More, A. W., \& Ambekar, S. S. (2010). Genetic variability and correlation studies in elite „, $\mathrm{B}^{\mathrm{ee}}$ and „, $\mathrm{R}^{\mathrm{ec}}$ lines in kharif sorghum. Electronic Journal of Plant Breeding. 1(4), 989-993.

Jindla, L. N., \& Gill, K. S. (1984). Inter-relationship of yield and its component characters in pearl millet. Crop Improvement, 11, 43-46.

Johnson, H. E., Robinson, H. F., \& Comstock, R. E. (1955). Estimates of genetic and Environmental viability of soybean. Agronomy Journal, 47, 314-318. https://doi.org/10.4238/2014.November.27.9

Kempthorne, O. (1957). An Introduction to Genetic Statistics. John Wiley and Sons. Inc., New York.

Mahmoud, K. M. (2007). Performance, heterosis, combining ability and phenotypic correlations in grain sorghum [Sorghum bicolor (L.) Moench]. Egyptian Journal of Applied Sciences, 22, 389-406.

Menezes, C. B., Ticona-benavente, C. A., Tardin, F. D., \& Cardoso, M. J. (2015). Selection indices to identify drought-tolerant grain sorghum cultivars. Genet. Mol. Res., 13, 9817-9827. https://doi.org/10.4238/2014.November.27.9

Moctar Kante, Henry Frederick W. Rattunde,Willmar L. Leiser,Baloua Nebié,Bocar Diallo,Abdoulaye Diallo,Abocar Oumar Touré,Eva Weltzien,Bettina I.G. Haussmann. (2017). Can Tall Guinea-Race Sorghum Hybrids Deliver Yield Advantage to Smallholder Farmers in West and Central Africa. crop science, 57, march-april 2017. https://doi.org/10.2135/cropsci2016.09.0765

Nimbalkar, V. S., Bapat, D. R., \& Patil, R. C. (1988). Components of grain yield in sorghum. Journal of Maharashtra Agricultural University, 13, 206-207. https://doi.org/10.22271/phyto.2020.v9.i2p.10979.

Rattunde, H. F. W., E. Weltzien, B. Diallo, A. G. Diallo, M. Sidibe, A. O., \& Touré et al. (2013). Yield of photoperiod-sensiltive sorghum hybrids based on guinea-race germplasm under farmers' field conditions in Mali. Crop Sci., 53, 2454-2461. https://doi.org/10.2135/cropsci2013.03.0182

Sankarapendium, R., Ramalingam, J., Pillai, M. A., \& Vanniiarajan, C. (1994). Heterosis and 


\section{Macrothink}

Journal of Agricultural Studies

ISSN 2166-0379 2022, Vol. 10, No. 1

combining ability studies for juice yield related characteristics in sweet sorghum. Ann. Agric Res., 15(2), 199-204.

Singh, B., \& Govila, O. P. (1989). Inheritance of grain size in pearl millet. Indian Journal of Genetics and Plant Breeding, 49, 63-65.

Toure, A. (2018). Développement des lignées de sorgho [Sorghum bicolor (L.) Moench] fortifiées, à haut potentiel de rendement, adaptées aux zones soudano-sahéliennes du Mali (unpublished doctoral dissertation) Thèse de Doctorat pour l'obtention du titre de Docteur de l'Institut Supérieur de Formation et de Recherche Appliquée (ISFRA) de Bamako. 146 pages.

Wright, S. (1921). Correlation and causation. Journal of Agricultural Research, 20, 557-587. https://doi.org/10.2307/2287275

\section{Copyrights}

Copyright for this article is retained by the author(s), with first publication rights granted to the journal.

This is an open-access article distributed under the terms and conditions of the Creative Commons Attribution license (http://creativecommons.org/licenses/by/4.0/) 